Ethnobiology and Conservation 2019, 8:1 (28 November 2018) doi:10.15451/ec2019-01-8.01-1-39

ISSN 2238-4782 ethnobioconservation.com

\title{
Trends on mexican ethnozoological research, vertebrates case: a systematic review
}

Tania Vianney Gutiérrez-Santillán1; Ulysses Paulino Albuquerque²; David Valenzuela-Galván³; Francisco Reyes-Zepeda1; Luis-Bernardo Vázquez ${ }^{4}$; Arturo Mora-Olivo ${ }^{1}$ and Leonardo Uriel ArellanoMéndez ${ }^{1, *}$

\begin{abstract}
Systematic reviews and meta-analytical approach are a tool used in different social and biological disciplines, but its application in evaluating ethnobiological information is scarce. Thus, through this analytical approach, we seek to answer if there are any patterns in the mexican ethnozoological scientific production. We searched for studies published between 2005 and 2015 in catalogues, repositories and databases. For evaluating significative differences among seven variable datasets, we first used non parametric Kruskal-Wallis tests and then Tukey multiple comparison tests. We also determined the link between researchers and institutions with a multidimensional non-metric scaling analysis. We found 295 published studies, book chapters were the most representative (27\%), diffusion articles $(20 \%)$, impact factor articles (15\%) and indexed articles (14\%). There are significant differences in the number of publications among the evaluated years, among thematic areas, study focus (qualitative/quantitative), ethnographic and biological methods. Regarding academic linking, we identified 94 author adscription institutions, however, no research networks were identified. Our results suggest that the amount, diffusion and reach of mexican ethnozoological production show a tendency to non-periodic publishing, predilection for qualitative approach, a low use of statistical and ethnobiological analysis, as well as an inadequate selection of biological methods. We suggest this data analysis approach will allow a better standardization for information taking and processing, aiding the discipline in its growth and consolidation.
\end{abstract}

Keywords: Systematic Reviews; Meta-Analysis; Ethnozoology

\footnotetext{
1 Instituto de Ecología Aplicada, Universidad Autónoma de Tamaulipas, México.

2 Departamento de Botânica, Laboratório de Ecologia e Evolução de Sistemas Socioecológicos, Universidade Federal de Pernambuco, Cidade Universitária, Recife, Pernambuco, Brasil.

${ }^{3}$ Centro de Investigación en Biodiversidad y Conservación, Universidad Autónoma del Estado de Morelos, México.

${ }^{4}$ Departamento de Agricultura, Sociedad y Ambiente, El Colegio de la Frontera Sur Unidad San Cristóbal de Las Casas, Chiapas, México.

* Corresponding author $\square$

E-mail address: TVGS (tvgutierrez_santillan@yahoo.com.mx), UPA (upa677@hotmail.com),DVG (dvalen@uaem.mx), FRZ (freyes@docentes.uat.edu.mx), LBV (I.b.vazquez@gmail.com), AMO(amorao@docentes.uat.edu.mx) and LUAM (leo.arellano.mendez@gmail.com)
} 


\section{INTRODUCTION}

Large scale information reviews and synthesis have been used in several disciplines as a new way for research (Kueffer et al. 2011), which are of two types: systematic reviews and meta-analyzes, they're both useful for large data sets management and study, generating information for the theory development, in general (Lortie 2014). On the one hand, systematic reviews develop explicit methods to evaluate and filter information, allowing a replicable, but usually qualitative, review (Egger and Smith 1997). On the other hand, meta-analyzes are statistical models, a mathematically simplified way of reality approaching provided by the data, integrating multiple independent studies, quantifying effects, describing processes structure, identifying patterns; thus allowing to increase the data reliability and identifying information gaps or omissions (ArchMiller et al. 2015; Gates 2002; Koricheva and Gurevitch 2014).

This type of approach has been used in social, biomedical and biological sciences (Arnqvist and Wooster 1995; Gates 2002). In ecology, they constitute a tool for the evaluation of research questions and decision-making based on evidence (Gates 2002). They are a promising future, by considering them as a means for primary research follow-up, researchers collaboration, financing funds optimal use, analytical strategies generators and large data sets integrators. Thus allowing us to emit critical recommendations, supporting scientific disciplines theoretical and methodological growth (Lortie 2014; Stewart 2009).

In ethnobiology, the use of meta-analysis has been proposed as a macroscopic approach, to identify knowledge patterns and the use of natural resources (Albuquerque and Medeiros 2012), becoming a method that helps to understand the socio-ecological systems complexity. Suggesting that ethnobiological information integration, not to be only descriptive, but should be based on analytical support. For example, TorresAvilez et al. (2016), develop a metaanalytical approach to identify patterns in knowledge among men and women concerning the use of medicinal plants at the local, continental and global levels; demonstrating that there is no gender pattern for knowledge at different scales; generating one of the first meta-analysis applications in ethnobiology.

Instead, systematic reviews have had greater application in ethnobiology. This is reflected in compilation studies such as latinamerican ethnobiological production for the last 50 years (Albuquerque et al. 2013) and in the evaluation of ethnozoology impact and development in Brazil (Lyra-Neves et al. 2015). In Mexico, they have been used to describe trends in knowledge, use, exploitation and domestication of plant resources (Bye and Linares 2000; Caballero et al. 1998). Several authors have documented the state of the art of ethnozoology for over a hundred years, reporting an increase in publications, a diversity of thematic areas, several indigenous groups and geographical areas (Argueta-Villamar et al. 2012; Brand 1962; Santos-Fita et al. 2012a). Also the description of the role of wildlife in traditional medicine (Alonso-Castro 2014).

Ethnozoology has positioned itself as one of ethnobiology's fundamental subdisciplines, focusing on the study of perceptual, cognitive and pragmatic relationships regarding fauna and human communities (Hunn 2011) understanding these relationships is fundamental for the 
conservation and exploitation of zooculturally important species of vertebrates and invertebrates (Alves and Souto 2015). The increase in ethnozoological research provides primary information for developing meta-analytical approach and thus identifying trends, that is, the behavior pattern of ethnozoological research elements. In this case, the trends in mexican ethnozoological production regarding contribution variations in a given period of time (2005-2015), the types of generated documents, the diversity of addressed thematic areas, the ethnographic and biological methods used. Meta-analytical approach development allows to visualize a general and real landscape of the discipline, to detect research gaps and thus contribute with other forms of analysis; stating the basis for later studies.

Therefore, we evaluated the trends in ethnozoological production for wild vertebrates in Mexico, emphasizing their reach and diffusion at a national and international level, considering the following hypotheses: 1) Contributions are variable in the analyzed time period, having some years with greater production than others; 2) The different types of publications (indexed articles, divulgation articles, books, book chapters, undergraduate and postgraduate theses) directly contribute to the reach and diffusion, therefore the indexed and impact factor publications have an international effect, while the other document types only have a national level impact; 3) The research diversity from several thematic areas provide a wider access for the discipline, so all the involved areas must meet the methodological criteria at the ethnographic and biological level; 4) The research approach (qualitative/quantitative) is related to the selection of ethnographic and biological methods, so both approaches must reflect an adequate methodological development; 5) The increase in ethnozoological research reflects the connection between researchers and institutions, this guarantees the discipline's consolidation. All these variables will allow to recognize the current trends of ethnozoology in Mexico, and at the same time, identify if there are any information gaps, allowing us to issue recommendations for its development, standardization and consolidation.

\section{MATERIAL AND METHODS}

\section{Publishing selection}

We searched for ethnozoological publications for wild vertebrates conducted between 2005 and 2015 following a hierarchical method. In the first place, we made an electronic search in catalogues, repositories and databases at the Web of Science (www.isiknowledge.com), Scopus (www.scopus.com) and the Consorcio Nacional de Recursos de Información Científica y Tecnológica de México (www.conricyt.mx). In the second stage, through direct author contributions; this is followed by a review of the publications cited literature, since some of the documents included in this review are not available on the internet. However, we assume that this complementary method may bias the data integration and the results, but we decided to continue in order to integrate as much information as possible.

The publications search was carried out from January to December 2015, collecting publications from 1936 to 2015. Arbitrarily delimiting information between 2005 and 2015 , so additionally, to find out if the included data within this time frame was 
statisically representative for the minimum sample size, we used the Cochran test (1953); the result was represented by a total of 202 publications with a 95\% confidence level, amount reached between 2015 and 2010. Therefore, the established time frame (2005-2015) did not just allow to have a representative sample, but to consider the entire data population.

The search terms were established by using a combination of keywords, fulfilling with one of the criteria for meta-analytical approach development (Gates 2002). The first one was to frame the discipline (Ethnozoology, Ethnobiology, Ethnoecology), the second one was for determinating the object of study (mammals, birds, reptiles, amphibians, fish), the third one included thematics (perception, knowledge, use, management, traditional classification) and the fourth one was the geographic region (Mexico).

We made a spatial analysis by using the recorded coordinates within the checked articles. This information was georreferenced, and when there were no coordinates, they were assigned through study zones description (locality, municipality, state) by using the Google Earth software (2016). In order to get the sample spatial representation, we used the publications georreferences, geographic territories (localities, municipalities and federative entities), vegetation types and indigenous territories as layers (De Ávila 2008); using the ArcView GIS Ver. 3.2 software (ESRI 1999).

\section{Inclusion criteria, data extraction and variables coding}

The types of publications included in this review were articles with an impact factor, indexed articles (without an impact factor), dissemination articles, books, book chapters, graduate and postgraduate theses; every publication had assigned an identification number, nationals and internationals. A database composed of four information sets was built. We worked with categorical variables to which a value (coding) was assigned; a variable could work as independent and/or dependent according to the type of evaluating tendency. Some variables were completed with additional information from an online search (e.g. impact factor, indexing). Information sets description, variables and values assignment are shown in Table 1.

\section{Data analysis}

A non-parametric Wilcoxon test was run through the STATISTICA software (StatSoft 2004), in order to determine if there are any significant differences in annual production, using data from publications for years. We also performed Kruskal-Wallis ANOVA (K-W) tests for independent groups, followed by Tukey's multiple comparison test (Zar 2010). The significant differences between the types of publications and the years of study, the reach (national or international) and the thematic areas were evaluated. We exclusively analyzed the data corresponding to articles with impact factor, indexed and divulgation; in relation to the reach and thematic areas. In general, methodological aspects were explored by relating the diversity of thematic areas and the research focus (qualitative/quantitative); the objectives and hypotheses establishment and the selection of ethnographic methods. Likewise, the relationship between ethnographic methods and the use of ethnographic tools (types of interviews) was evaluated, as well as the selection of biological field methods for data collection and species taxonomic 
Table 1. Legend: Variables categorization, the number in parentheses represents the assigned value.

\begin{tabular}{|c|c|c|}
\hline Variable & Type & Description \\
\hline Year & discrete & Range: 2005 to 2015 \\
\hline $\begin{array}{l}\text { Publication } \\
\text { types }\end{array}$ & $\begin{array}{l}\text { categorical/ } \\
\text { coded }\end{array}$ & $\begin{array}{l}\text { Impact factor article (1), index article (2), scientific diffusion } \\
\text { article (3), book (4), book chapter (5), others (6; institutional } \\
\text { website and project), postgraduate thesis ( } 7 \text {; doctorate, } \\
\text { master), undergraduate thesis ( } 8 \text {; monographs, } \\
\text { professional residency records) }\end{array}$ \\
\hline Reach & discrete & international (1), national (2) \\
\hline Impact factor & discrete & $\begin{array}{l}\text { impact factor (1), no impact factor ( } 2) \\
\text { ethnozoology } \quad(1), \quad \text { ethnodisciplines } \quad(2 ; \quad \text { ethnobiology, }\end{array}$ \\
\hline Discipline & $\begin{array}{l}\text { categorical/ } \\
\text { coded }\end{array}$ & $\begin{array}{l}\text { ethnobotanics, ethnoecology, ethnopharmacology, } \\
\text { ethnohistory), biology (3), anthropology (4), others (5; } \\
\text { medicine, geography, generals) }\end{array}$ \\
\hline Obje & disc & yes (1), no (2) \\
\hline Hypothesis & discrete & yes (1), no (2) \\
\hline $\begin{array}{l}\text { Ethnographic } \\
\text { method }\end{array}$ & $\begin{array}{l}\text { categorical/ } \\
\text { coded }\end{array}$ & $\begin{array}{l}\text { statistical (1; random, probabilistic), ethnobiological (2; } \\
\text { snowball, stratus, key informants, banking memory, } \\
\text { percentage, participatory appraisal), bibliographical (3), } \\
\text { unspecifical (4) }\end{array}$ \\
\hline $\begin{array}{l}\text { Ethnographical } \\
\text { tool }\end{array}$ & $\begin{array}{l}\text { categorical/ } \\
\text { coded }\end{array}$ & $\begin{array}{l}\text { specifical interviews (1; open, directed, structured, } \\
\text { semistructured, free multiple listing interviews), interview } \\
\text { (2), workshops (3), informal (4), bibliographical (5), multiple } \\
\text { (6), unspecifical(7) }\end{array}$ \\
\hline Research type & discrete & qualitative (1), quantitative (2), unspecifical (3) \\
\hline Data analysis & discrete & $\begin{array}{l}\text { statistics (1; parametric, nonparametric, multivariate), } \\
\text { ethnobiological (2; index of cultural importance, use value), } \\
\text { multiple (3), biological (4), none (5) }\end{array}$ \\
\hline $\begin{array}{l}\text { Biological } \\
\text { method }\end{array}$ & $\begin{array}{l}\text { categorical/ } \\
\text { coded }\end{array}$ & $\begin{array}{l}\text { biological ( } 1 \text {; sightings, nets, collections, photocameras, } \\
\text { bioassays, biological collections), records ( } 3 \text { ), etnobiological } \\
\text { ( } 3 \text {; biocultural tours, traditional names, field guides, visual } \\
\text { stimuli, interviews), multiple (4), unspecifical (5) }\end{array}$ \\
\hline $\begin{array}{l}\text { Taxonomical } \\
\text { group }\end{array}$ & $\begin{array}{l}\text { categorical/ } \\
\text { coded }\end{array}$ & $\begin{array}{l}\text { mammals (1), birds (2), amphibiansand/or reptiles (3), fish } \\
\text { (4), combined (5), unspecifical (6) }\end{array}$ \\
\hline
\end{tabular}

identification.

Finally, ethnozoological study networks were identified through a non-metric multidimensional scaling analysis (NMDS). By identifying universities or institutions with a bigger ethnozoological production contribution, as well as associated researchers. We used the Past 3.07 statistical software (Hammer et al. 2001) and as a similarity measure the Euclidean distances, where the variables corresponded to the institutions, and the observations corresponded to the authors.

\section{RESULTS}

\section{Generalities ethnozoological}

We got 295 publications for the 20052015 period (Suplementary Material), of which the most representative are the book chapters and the divulgation articles being the $47 \%$ of the sample. The main studies contribution comes from the ethnozoological area $(63 \%)$, but contributions from other disciplines are also available. On the other hand, when analyzing some methodological aspects it is observed that most of the 
researches are framed to a goal, but only a few state a hypothesis.

Most publications do not report the selection of their ethnographic methods, of which only $2 \%$ have chosen representative methods at a statistical level. About the ethnographic tools, a combination of techniques is usually used (e.g. interview, participatory observation, workshops). Continuing with methodological aspects, there is a predilection for qualitative approach research $(60 \%)$, so the data analysis application at the statistical, ethnobiological and biological level is uncommon (25\%). Regarding field biological methods, half the publications don't report which technique did they use. The vertebrate groups with the largest number of studies are mammals and birds (Table 2).

On the other hand, the publications spatial representation is heterogeneous (Fig. 1). The geographic territories information is:
242 localities, in 177 municipalities, in 27 of the 32 states of the Mexican Republic; including the states of: Baja California, Campeche, Chiapas, Chihuahua, Mexico City, Durango, State of Mexico, Guanajuato, Guerrero, Hidalgo, Jalisco, Michoacan, Morelos, Nayarit, Oaxaca, Puebla, Queretaro, Quintana Roo, San Luis Potosi, Sinaloa, Tabasco, Tamaulipas, Tlaxcala, Veracruz, Yucatan and Zacatecas.

The studies in general include these types of vegetation: temperate forests (pineoak), boreal forests (cloud forest), tropical forests (high, medium and low, evergreen, subperenlifolio, deciduous and subdeciduous) shrubs, as well as agricultural areas. Reported indigenous groups represent $52 \% \quad(n=32)$ of the total, corresponding to: Amuzgo, Cho'l, Chinantec, Chontal from Oaxaca, Chontal from Tabasco, Cucupa, Cuicateco, Huasteco, Huave, Huichol, Kiliwa, Maya, Mayo,

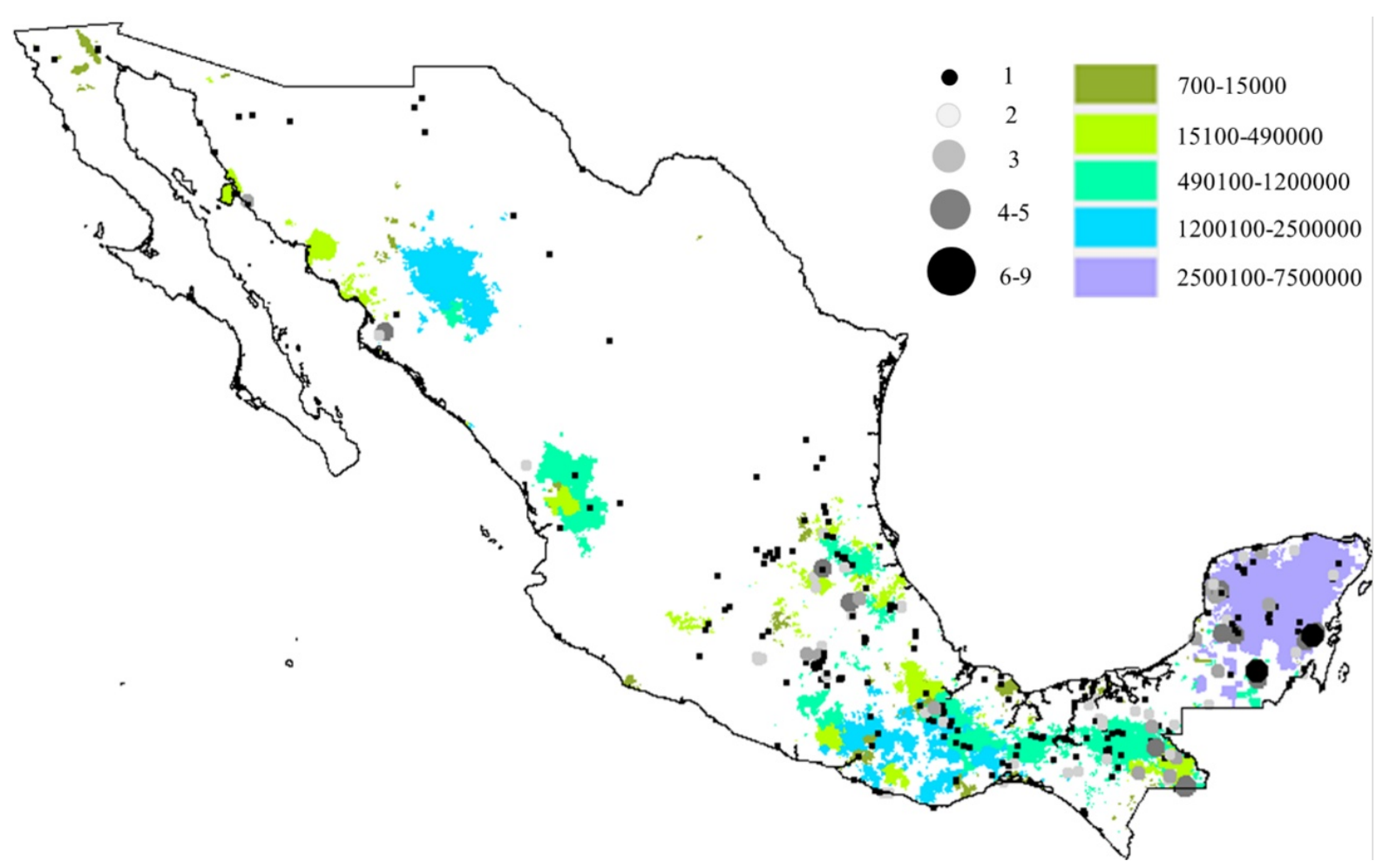

Figure 1. Distribution of ethnozoological publications and indigenous territories in Mexico (the points represent the number of publications per site, while the colored boxes the indigenous area in hectare). 
Table 2. Legend: Publications descriptive data

\begin{tabular}{|c|c|}
\hline Generalities & Description \\
\hline $\begin{array}{l}\text { Number } \\
\text { Publications } \\
\text { between } \\
2015\end{array}$ & $\begin{array}{l}\text { The years with the larger number of papers are } 2010(n=59), 2011 \\
(n=39), 2014 \quad(n=38) \text { and } 2012(n=31) \text { representing } 57 \% \text { of the total } \\
\text { sample. The remaining percentage is represented between the years } \\
2013(n=29), 2008(n=22), 2009(n=19), 2007(n=17), 2006 \quad(n=16) \\
\text { and } 2015(n=11) \text {. }\end{array}$ \\
\hline $\begin{array}{l}\text { Publication types } \\
\text { and reach }\end{array}$ & $\begin{array}{l}\text { There are book chapters }(27 \%) \text {, scientific diffusion articles }(20 \%) \text {, } \\
\text { impact factor articles }(15 \%) \text {, index articles }(14 \%) \text {, undergraduate thesis } \\
(11 \%) \text {, postgraduate thesis }(9 \%) \text {, books }(3.5 \%) \text { and others }(0.5 \%) \text {. Of } \\
\text { the total sample, } 75 \% \text { have a national or local impact, so } 25 \% \text { is at an } \\
\text { international level. }\end{array}$ \\
\hline Thematic areas & $\begin{array}{l}63 \%(n=188) \text { of the research are developed from ethnozoology, } 11 \% \\
(n=32) \text { from ethnosciences, } 20 \%(n=60) \text { from biological areas, } 4 \%(n= \\
\text { 10) from the anthropological areas and } 2 \%(n=5) \text { from other } \\
\text { disciplines. }\end{array}$ \\
\hline $\begin{array}{l}\text { Methodological } \\
\text { aspects }\end{array}$ & $\begin{array}{l}80 \% \text { of research is based on a research question or objective, } \\
\text { however, only } 2 \% \text { poses a hypothesis. In addition, } 2 \% \text { developed a } \\
\text { statistical ethnographic method, } 27 \% \text { ethnobiological, } 10 \% \\
\text { bibliographical and } 60 \% \text { non-specific. This is related to the type of } \\
\text { ethnographic tool, where } 25 \% \text { use a combination of techniques, } 24 \% \\
\text { doesn't specify, } 19 \% \text { reports some type of interview, } 15 \% \text { only admits } \\
\text { using an interview format without specifying what type, } 2 \% \text { organized } \\
\text { participatory workshops and } 1 \% \text { used informal information. }\end{array}$ \\
\hline $\begin{array}{l}\text { Focus and data } \\
\text { analysis }\end{array}$ & $\begin{array}{l}\text { There is a predilection for developing qualitative research }(60 \%), 25 \% \\
\text { of the information is quantitative, but there are a number of papers that } \\
\text { don't report any approach ( } 15 \%) \text {. The quantitative approach is related } \\
\text { to the data analysis, in this case were considered as quantitative all } \\
\text { papers reporting the use of statistical tests }(9 \%) \text {, data analysis with } \\
\text { ethnobiological indexes }(8 \%) \text {, analysis type combinations }(7 \%) \text { and } \\
\text { biological indexes }(1 \%) \text {. }\end{array}$ \\
\hline $\begin{array}{l}\text { Biological method } \\
\text { and vertebrate } \\
\text { classes }\end{array}$ & $\begin{array}{l}\text { Most investigations choose to work more than two vertebrate classes } \\
(30 \%) \text {. The best represented class is mammals with } 22 \% \text {, followed by } \\
\text { birds with } 20 \% \text {, amphibians and reptiles with } 12 \% \text { and the least worked } \\
\text { class are fish with only } 2 \% \text {. Vertebrate classes are associated with } \\
\text { field methods and their taxonomic identification, however, it is } \\
\text { observed that } 50 \% \text { of the publications do not report the type of } \\
\text { biological method, } 23 \% \text { is based on previous species records, } 12 \% \text { in } \\
\text { ethnobiological methods, } 8 \% \text { use combined techniques and only } 4 \% \\
\text { report some field technique. }\end{array}$ \\
\hline
\end{tabular}

Mazahua, Mazateco, Mixe, Nahuatl, Ñhañhu, Paipai, Pima, Seri, Purhepecha, Tepehua, Tepehuano, Tlahuica, Tojolabal, Triqui, Tseltal, Tsoltil, Zapoteco and Zoque; the Afro-Mexican and mestizo populations were also included.

\section{Meta-analytical approach}

Meta-analytical approach ethnozoological production shows a significant difference in the number of publications between the evaluated years $(z=14.8870, p<0.05$, Fig. $2 a)$. So do the types of publication when linking to national and international level reach $(H=140.6785, p<0.05$; Fig. $2 b)$, as well as with thematic areas $(H=18.6838, p<0.05)$.

Concerning the publication types, we only analyzed the article corresponding data sets (impact factor, indexed and divulgation), 

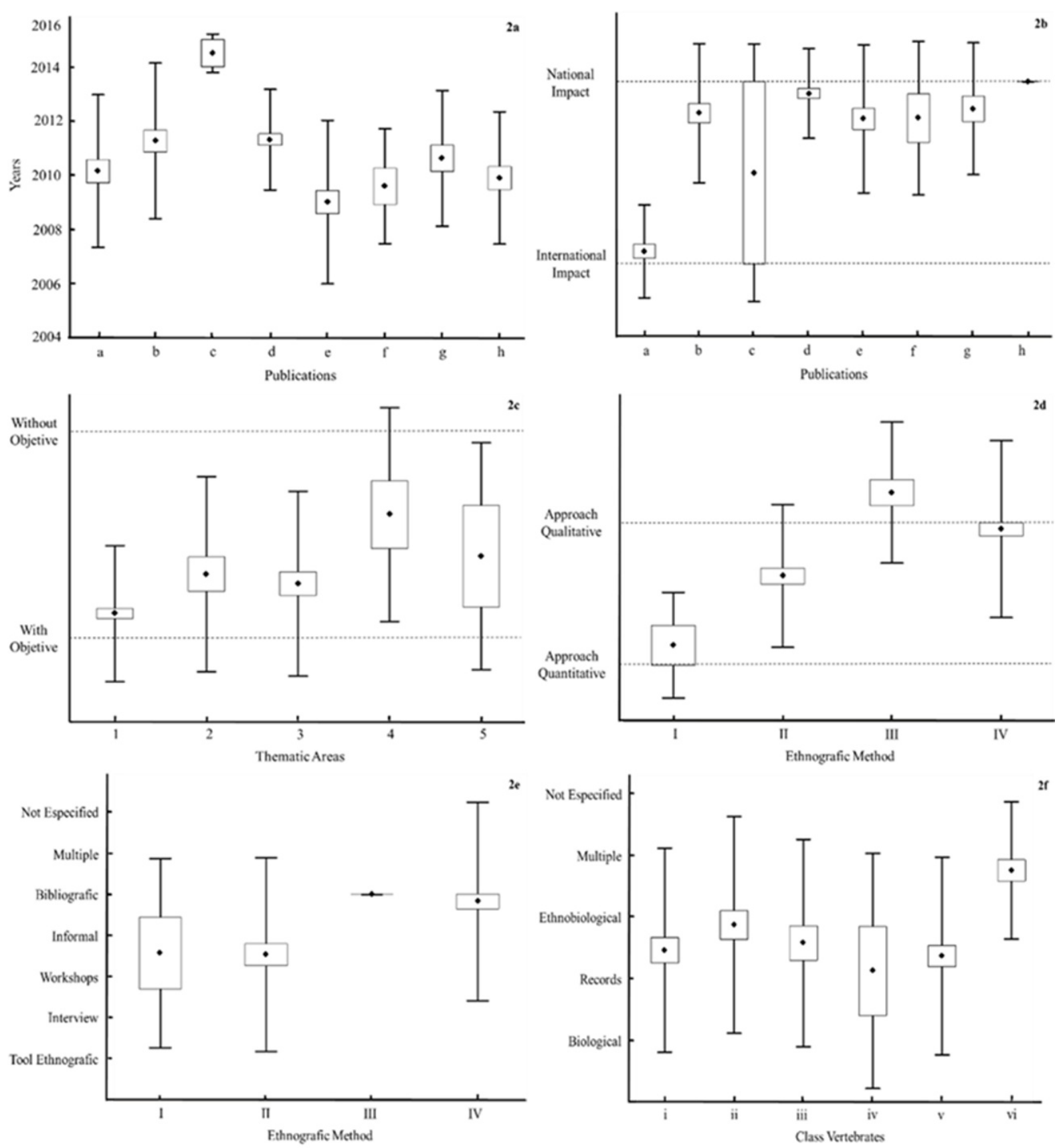

Figure 2. Meta-analysis. 2a. Relation between the evaluated years and the publication types $(\mathrm{a}=$ article with impact factor, $b=$ indexed article, $c=$ other, $d=$ book chapter, $e=$ scientific diffusion article, $f=$ book, $g=$ postgraduate thesis, $h=$ undergraduate thesis), $2 b$. Reach (national or international) and types of publications, 2c. Establishment of research objectives and thematic areas ( $1=$ ethnozoology, 2 = ethnodiscipline, $3=$ biological, $4=$ anthropology, $5=$ another), $2 \mathrm{~d}$. Research focus (qualitative $/$ quantitative) and ethnographic method (I = statistical, II = ethnobiological, III = bibliographic, VI = unspecifical), 2e. Type of ethnographic tool and ethnographic method, 2f. Biological field method and vertebrate class $(\mathrm{i}=$ Mammalia, $\mathrm{ii}=$ Birds, $\mathrm{iii}=$ Amphibia and Reptilia, $\mathrm{iv}=$ Pisces, $\mathrm{v}=$ combined, $\mathrm{vi}=$ unspecified). 
showing a statistical variation in the production and the national and international level reach $(H=69.4995, p<0.05$; Fig. 3a). At the international level, the trend is given within the articles published in impact factor journals $(n=44)$, in a range between 0.194 and 4.165. The journals with the larger amount of publications are: Human Ecology, Interciencia, Journal of Ethnopharmacology and Journal of Ethnobiology and Ethnomedicine (Table 3). We watched another trend when linking the impact factor, indexed and divulgation articles with thematic areas $(H=14.9216, p<0.05$; Fig. $3 b)$. Where the main impact factor articles contribution is encouraged from biological areas; while ethnozoology and the other ethnodisciplines produce a bigger amount of indexed (without impact factor) and divulgation articles.

Mostly, when analyzing the methodological approach variable (qualitative/quantitative) the trend is in the qualitative research development, showing it is significant in relation to thematic areas $(\mathrm{H}=20.0930, p<0.05)$. There are also statistical differences between the different thematic areas and the goals setting or research questions $(\mathrm{H}=22.9639, \mathrm{p}<0.05$; Fig. 2c). On the other hand, when relating the "ethnographic method" and "thematic areas" variables, this didn't show statistical variation, indicating that there is no predilection for any particular method. However, it did show up when analyzing the types of ethnographic methods and the qualitative or quantitative research approach $(H=35.8335, p<0.05$, Fig. $2 d)$. As well as linking the ethnographic methods with the types of data analysis $(\mathrm{H}=24.5070, \mathrm{p}<0.05)$. A methodological section indicative variable is the type of ethnographic tool (type of interview) which, linked to ethnographic methods, shows a variation in the selection
$(H=26.1134, p<0.05$, Fig. 2e). At last, another evaluation parameter was the biological field method for species data collecting, which, when related to biological groups, show statistical differences $(H=27.1214, \quad p<0.05$, Fig. 2f). The description of the internal heterogeneity between the relationship of the variables is described in Table 4.

\section{Ethnozoological networks \\ academic}

There were 94 institutions with affiliated authors, of which $56 \%$ corresponded to national institutions and $42 \%$ to international institutions. $93 \%$ of the citations were concentrated in 58 institutions (national and international), amount obtained from all those institutions that were represented at least twice in the sample.

The result in the NMDS analysis shows the lack of linkage and thus the absence of networks between institutions and authors $(n=426)$, from which $72 \%$ are represented only once, while the rest rank from 2 to 27 citations, in which they're not necessarily as the primary or correspondence author, in this category we didn't consider if they were interdisciplinary groups leaders, coparticipants or students (Fig. 4).

The universities with the highest number of citations are: Universidad Nacional Autónoma de México ( $n=91)$, Colegio de la Frontera Sur Unidad San Cristóbal de las Casas - Chiapas $(n=79)$, Universidad Autónoma de Campeche $(n=28)$, Centro de Investigación y de Estudios Avanzados del Instituto Politécnico Nacional - Unidad Mérida ( $n=22)$ and Instituto Tecnológico del Valle de Oaxaca $(n=21)$. 


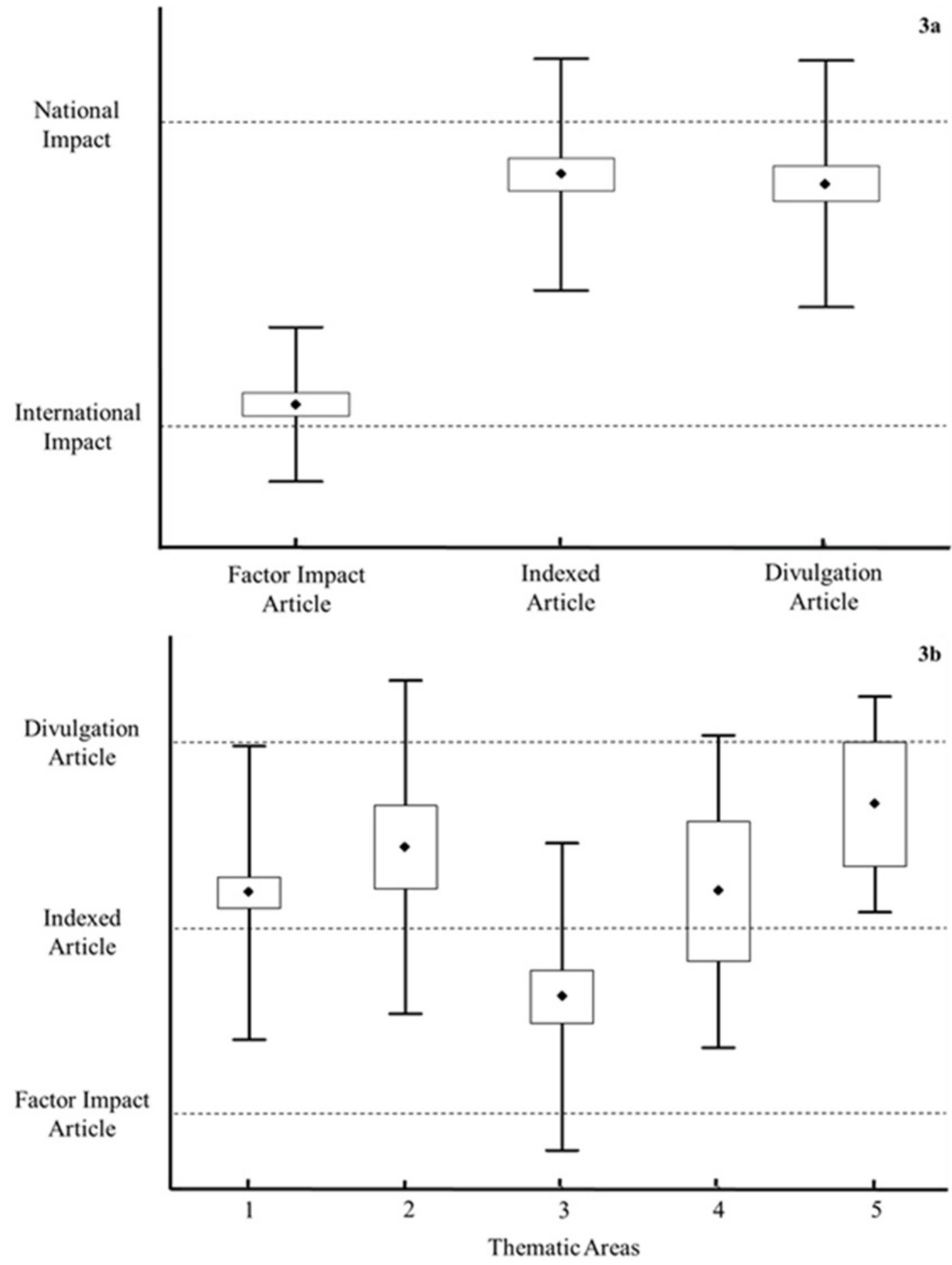

Figure 3. Meta-analysis considering only articles with impact factor, indexed articles and scientific diffusion articles. 3a. Relationship between types of articles and reach at national or international level. 3b. Relationship among thematic areas $(1=$ ethnozoology, $2=$ ethnodiscipline, $3=$ biological, 4 $=$ anthropology, $5=$ other) and article types. 
Table 3. Citations that correspond to journals with impact factor in which articles of mexican ethnozoology have been published in a period from 2005-2015.

NOTE: The update of the impact factor of the journals was done on October 25, 2017.

\begin{tabular}{|c|c|c|c|}
\hline Journal & $\begin{array}{l}\text { Impact } \\
\text { Factor }\end{array}$ & $\begin{array}{l}\text { Number of } \\
\text { publications }\end{array}$ & Citations \\
\hline Conservation Biology & 4.842 & $(n=1)$ & Haenn et al. 2014 \\
\hline Biological Conservation & 4.022 & $(n=1)$ & Naranjo and Bodmer 2007 \\
\hline $\begin{array}{l}\text { Journal of } \\
\text { Ethnopharmacology }\end{array}$ & 2.981 & $(n=4)$ & $\begin{array}{l}\text { Alonso-Castro et al. 2011; } \\
\text { Jacobo-Salcedo et al. 2011; } \\
\text { Jacobo-Salcedo et al. 2013; } \\
\text { Alonso-Castro } 2014\end{array}$ \\
\hline $\begin{array}{l}\text { Journal of Research in } \\
\text { Crime and Delinquency }\end{array}$ & 2.545 & $(n=1)$ & Pires and Clarke 2012 \\
\hline $\begin{array}{l}\text { Biodiversity and } \\
\text { Conservation }\end{array}$ & 2.265 & $(n=2)$ & $\begin{array}{l}\text { Vázquez and Gaston 2006; } \\
\text { Reyna-Hurtado and Tanner } 2007\end{array}$ \\
\hline Oryx & 2.191 & $(n=2)$ & $\begin{array}{l}\text { Reyna-Hurtado et al. 2009; } \\
\text { Amador-Alcalá et al. } 2013\end{array}$ \\
\hline The Auk & 2.096 & $(n=1)$ & Haemig 2012 \\
\hline $\begin{array}{l}\text { Journal Ethnobiology and } \\
\text { Ethnomedicine }\end{array}$ & 1.903 & $(n=5)$ & $\begin{array}{l}\text { Santos-Fita et al. 2012, } \\
\text { Alcántara-Salinas et al. 2013; } \\
\text { Zamudio et al. 2013; García del } \\
\text { Valle et al. 2015; Santos-Fita et } \\
\text { al. } 2015\end{array}$ \\
\hline Human Ecology & 1.743 & $(n=6)$ & $\begin{array}{l}\text { Barragán et al. 2007; Arce-lbarra } \\
\text { and Charles 2008; León and } \\
\text { Montiel 2008; Garcia-Alaniz et al. } \\
\text { 2010; Mancini et al. 2011; } \\
\text { Basurto et al. } 2012\end{array}$ \\
\hline Biotropica & 1.73 & $(n=1)$ & Reyna-Hurtado and Tanner 2005 \\
\hline Acta Oecologica & 1.652 & $(n=1)$ & Kampichler et al. 2010 \\
\hline Journal of Ornithology & 1.468 & $(n=1)$ & Haemig 2010 \\
\hline $\begin{array}{l}\text { Fisheries Management } \\
\text { and Ecology }\end{array}$ & 1.327 & $(n=1)$ & Inda-Diaz et al. 2009 \\
\hline $\begin{array}{l}\text { The International Forestry } \\
\text { Review }\end{array}$ & 1.308 & $(n=1)$ & Ibarra et al. 2011 \\
\hline $\begin{array}{l}\text { Tropical Conservation } \\
\text { Science }\end{array}$ & 1.238 & $(n=3)$ & $\begin{array}{l}\text { Rodas-Trejo et al. 2008; López } \\
\text { del Toro et al. 2009; Oliva et al. } \\
2014\end{array}$ \\
\hline Journal Ethnobiology & 1.217 & $(n=2)$ & $\begin{array}{l}\text { Eckert and Clark 2009; } \\
\text { Rodriguez et al. } 2012\end{array}$ \\
\hline Wildlife Society Bulletin & 0.967 & $(n=2)$ & $\begin{array}{l}\text { Valdez et al. 2006; Weber et al. } \\
2006\end{array}$ \\
\hline $\begin{array}{l}\text { Revista Mexicana de } \\
\text { Biodiversidad }\end{array}$ & 0.596 & $(n=3)$ & $\begin{array}{l}\text { Delfín-Alfonso et al. 2008; Ávila- } \\
\text { Nájera et al. 2011; Almazán- } \\
\text { Catalán et al. } 2013\end{array}$ \\
\hline $\begin{array}{l}\text { Revista de Biología } \\
\text { Tropical }\end{array}$ & 0.495 & $(n=2)$ & $\begin{array}{l}\text { Gallina et al. 2012; Lira-Torres et } \\
\text { al. } 2012\end{array}$ \\
\hline Interciencia & 0.221 & $(n=5)$ & $\begin{array}{l}\text { Enríquez-Vázquez et al. 2006; } \\
\text { Romero-Balderas et al. 2006; } \\
\text { Monroy-Vilchis et al. 2008; } \\
\text { Toledo et al. 2008; García- } \\
\text { Grajales } 2013\end{array}$ \\
\hline
\end{tabular}


Table 4. Variables relation at a statistical level, using Tukey's multiple comparison

\begin{tabular}{|c|c|}
\hline Variables & Tukey's multiple comparison \\
\hline $\begin{array}{l}\text { Evaluation period } \\
(2005-2015)\end{array}$ & $\begin{array}{l}\text { The differences are not only shown between evaluated years, but also } \\
\text { when relating years with publication types }(H=30.8811, p<0.05) \text {; } \\
\text { heterogeneity shown between divulgation periods and indexed articles } \\
(z=3.9962, p<0.05) \text { and with book chapters }(z=4.0009, p<0.05 ; \text { Fig. } 2 a)\end{array}$ \\
\hline \multirow[t]{3}{*}{$\begin{array}{l}\text { Publication types, } \\
\text { and national and } \\
\text { international reach }\end{array}$} & $\begin{array}{l}\text { Publication types regarding to national and international reach show a } \\
\text { high heterogeneity among all the types of evaluated documents, e.g. } \\
\text { impact factor and indexed articles }(z=6.4048, p<0.05) \text {, divulgation } \\
\text { articles }(z=6.0587, p<0.05) \text {, book chapters }(z=7.9578, p<0.05) \text {, books } \\
(z=3.6120, p<0.05) \text { undergraduate thesis }(z=6.9967, p<0.05) \text { and } \\
\text { postgraduate thesis }(z=5.5429, p<0.05) \text {. }\end{array}$ \\
\hline & $\begin{array}{l}\text { There is also a statistical difference between publication types and } \\
\text { thematic areas, shown between impact factor articles and } \\
\text { undergraduate thesis }(z=3.1689, p<0.05) \text {. }\end{array}$ \\
\hline & $\begin{array}{l}\text { Another example happened exclusively for document type articles, } \\
\text { showing differences between impact factor and indexed articles } \\
(z=6.3937, p<0.05) \text {, and in turn, with divulgation articles }(z=6.0481, p \\
<0.05) \text {. }\end{array}$ \\
\hline Thematic areas & $\begin{array}{l}\text { The bigger difference for "thematic areas" variable, happens between } \\
\text { biological areas and ethnozoology }(z=2.9749, p<0.05) \text {. }\end{array}$ \\
\hline $\begin{array}{l}\text { Methodological } \\
\text { aspects }\end{array}$ & $\begin{array}{l}\text { The internal variation between the "ethnographic methods" and } \\
\text { "research approach" (qualitative/quantitative) variables is shown } \\
\text { between the statistical methods choosing against bibliographic ones, } \\
\text { as well as with publications that don't report any method type at all } \\
\text { ( } z=3.7296, \quad p<0.05 ; \quad z=3.0975, \quad p<0.05) \text {. In addition, between } \\
\text { ethnobiological methods against bibliographic works, and also with } \\
\text { those that don't report any method type ( } z=3.8975, p<0.05 ; z=3.4357 \text {, } \\
p<0.05) \text {. }\end{array}$ \\
\hline Data analysis & $\begin{array}{l}\text { Regarding data analysis, we watched a variation between statistical } \\
\text { methods and the ones of the bibliographical type }(z=3.1097, p<0.05) \\
\text { and those which don't specify no method at all }(z=2.7681, p<0.05)\end{array}$ \\
\hline $\begin{array}{l}\text { Ethnographic tools } \\
\text { (interviews) }\end{array}$ & $\begin{array}{l}\text { The variation between ethnographic method types and ethnographic } \\
\text { tools design (interviews) is present between the researches that don't } \\
\text { report the tool type regarding the use of ethnobiological tools } \\
(z=4.7507, p<0.05)\end{array}$ \\
\hline $\begin{array}{l}\text { Biological method } \\
\text { and vertebrate } \\
\text { classes }\end{array}$ & $\begin{array}{l}\text { The difference in biological methods development is shown between } \\
\text { the studies that don't report any species and the ones that report } \\
\text { mammals }(z=3.9220, p<0.05) \text {, also with herpetological data }(z=2.9810 \text {, } \\
p<0.05) \text { and with those that report more than two classes of } \\
\text { vertebrates }(z=4.4242, p<0.05) \text {. }\end{array}$ \\
\hline
\end{tabular}

\section{DISCUSSION}

\section{Meta-analytical approach}

The results suggest that there are significant differences in most of the analyzed variables, a trend observed when quantitatively analyzing the effect of variables that can't be perceived descriptively (Adams 2007; Stewart 2009). Our variables categorization based research, allowed the development of the metaanalytical approach with ethnobiological data (Albuquerque and Medeiros 2012; TorresAvilez et al. 2016) establishing variables that explain the effect magnitude and its 
variability (Arnqvist and Wooster 1995; Gates 2002; Koricheva and Gurevitch 2014; Stewart 2009). Thus, supporting trends and allowing the identification of information gaps (Egger and Smith 1997; Lortie 2014), that is, research development factors in which we must pay attention either at a conceptual, methodological or analytical level; contributing to the growth of the discipline and generating a new research culture (Adams 2007; Kueffer et al. 2011).

The first step for meta-analytical approach development is integrating primary information, which based on keyword sets meets one of the criteria, on information selection and studies are considered as independent samples (ArchMiller et al. 2015; Gates 2002). However, due to the publications diversity, it wasn't possible to include only those in article format, as well as complementing the sample with authors direct contributions. We assume that both factors contribute on generating biases in data integration and the analyzes. But we consider that as a whole the information is integrated to evaluate a more real panorama of the discipline. Emphasizing that all the included contributions had the variables corresponding data.

Regarding the data analysis, we observed that there is a discontinuity in the review period, because there are years in which the number of contributions increases, phenomenon related with the organization of academic events and the publication of chapter format books (Guerra-Roa et al. 2010; Moreno-Fuentes et al. 2010; SantosFita et al. 2012a; Vásquez-Dávila 2014). On the other hand, there is a heterogeneity in the publication types, which is determined by the diversity of thematic areas. Identifying a marked tendency between the publication of impact factor articles, biological areas and the application of quantitative methodologies. While from ethnozoology and anthropology to the publication of indexed articles (without impact factor), divulgation articles and book chapters; as well as the preference for qualitative research, the same trend described in other reviews (Lyra-Neves et al. 2015).

The evaluation about methodological aspects detected that the researches no matter the type of manuscript or thematic area are framed under one single goal, however, there are few cases in which a hypothesis is established. On the other hand, we also detected a confusion between the ethnographic method (selection of informants) and the ethnographic tools (interview format); usually assuming, that they're two similar methodological aspects (Albuquerque et al. 2014), affecting the informers sample type and their selection; as well as the ethnographic data gathering through interviews or other tools (LyraNeves et al. 2015).

We also detected that when relating the manuscript types with the thematic areas, there is a tendency in the application of statistical analysis and researches with a biological approach. Meanwhile in ethnozoology is preferred to apply ethnobiological indexes, such as cultural importance and use value. There is no index for ethnozoology to evaluate directly the zoocultural importance, since the ethnobiological indices have been designed for plants and fungi, which are integrated by sub-indices of each biological group and their ethnobiological parameters (GaribayOrijel et al. 2007; Phillips and Gentry 1993a; 1993b; Pieroni 2001; Turner 1988). Therefore, it is essential to design indexes that evaluate zoocultural importance, including animal exclusive variables, explaining their socio-cultural relationship. For example, the role of animals as pets, in 


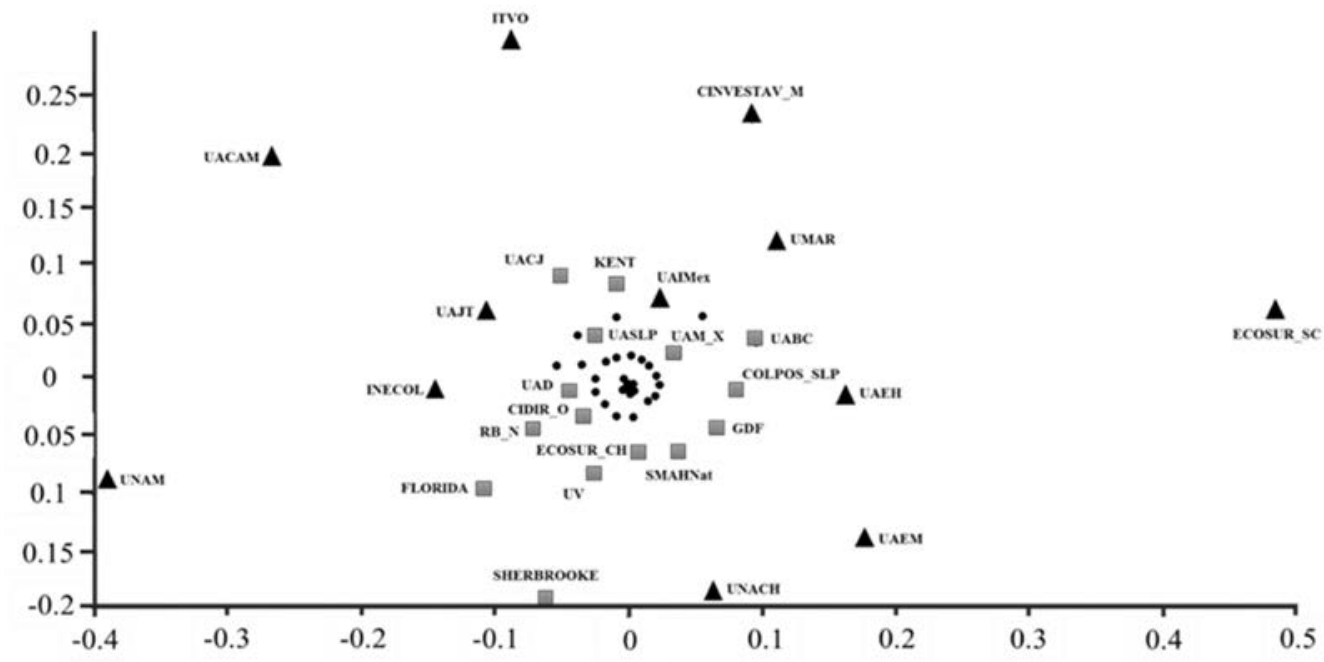

Figure 4. Institutions that have a sample contribution of more than 10 publications are represented with the triangle icon, while those that range between 9 and 5 publications with a square icon and those with less than 4 publications within the analyzed sample, with a point icon (stress value: $0.1681)$.

hunting and captivity activities; including oral tradition, symbolism, myths and arts (Alves 2012); or perceptual, ceremonial, ornamental and medicinal level; variables shared with plants and fungi but that operate differently for animals.

At last, in relation to the application of biological methods for the taxonomic identification of vertebrate species, on the one hand, methods of each biological group are used, but there is also a tendency to use published data on species records. As well as the application of ethnobiological methods, for example, the use of visual stimuli (Albuquerque et al. 2014; Alexiades 1996) or based on traditional nomenclature. However, ethnobiological methods don't provide a correct taxonomic identification. Therefore, it's essential to establish field methods to improve taxonomic identifications and their association with traditional nomenclature, knowledge and traditional practices.

Detecting such trends suggest paying attention to the lack of homogeneization within ethnozoological research, about what's being published (Lortie 2014) and how does this affect at a national and international level (Campos et al. 2016). This is not for thematic areas discrimination, nor considering quantitative method is better than qualitative. But there is a need to start framing ethnozoological researches with a more unified focus, independently from the thematic area they come from. This could give more methodological robustness and support in results interpretation (Albuquerque and Medeiros 2012; Campos et al. 2016); just as information production that helps for later studies, like metaanalytical approach development or new ethnobiological research programs (Albuquerque and Ferreira-Júnior 2017).

A bigger interest for developing ethnozoological research is evident, but we must consider that, for the discipline to impact at an international level, it is essential to produce indexed and impact factor articles. This publication type has a review from the editorial committee, evaluated by 
pairs, many are free access, with high online availability (Ladle et al. 2012; Lortie et al. 2013; Teixeira et al. 2013) and are cosidered fundamentals of science as a clear and well structured argument to support assumptions (Todd et al. 2007). Thus, the publications that don't fit under international publishing criteria, are considered as gray literature (Gates 2002) because they're local, low divulgation, low online access and a lack of an editorial rigor process (Campos et al. 2016; Ladle et al. 2012). This aspects generate an effect known as academical insularity, in which local authors are redundantly and wrongly cited, without giving credit to original ideas; thus generating a low scientific contribution (Campos et al. 2016; Ladle et al. 2012; Lortie et al. 2012; Teixeira et al. 2013).

However, it must be considered that the low ethnozoological research input under indexed and impact factor article formats at a national and international level, is due to a lack of specialized, open access journals, high publishing costs (Campos et al. 2016; Ladle et al. 2012) and the reduced or null research budget. There are international impact factor journals at the ethnobiology area and even ethnobotanics, but not in ethnozoology, despite being a discipline that has been taking its boom for the last years at an international level (Alves 2012; Alves and Souto 2015). Aspects which directly affect and difficult contributions to the discipline, its consolidation, divulgation and access.

\section{Ethnozoological networks}

Information macroscopical approach provides a general landscape about ethnozoological research networks within the country. Showing a reduced linkage between researchers and national institutions, and these to the international level. We can quote the interest for research groups aiming to establish agendas and forming research networks. For example, the thematic network in Ecología y Patrimonio Biocultural, supported by Consejo Nacional de Ciencia y Tecnología CONACyT (http://etnoecologia.uv.mx/Red_paginaprinci pal.html); however, the network approach includes all ethnobiological areas, as well as other disciplines.

The reduced linkage between institutions and researchers reflects the lack of consolidated researchers, low formation of new human capital and thus the recent creation of study groups. This has an indirect influence in its consolidation, publishing, ampact and diffusion at a national and international level (Albuquerque et al. 2013; Campos et al. 2016; Sutherland et al. 2013).

However, one of the most outstanding cases about the growth and consolidation of ethnozoology has been shown by the Brazilian scientific community, which can be a reference for Mexico. The Brazilian strategy is characterized by the periodic publication of ethnozoological articles in impact factor journals at ethnobiological discipline areas (e.g. Journal of Ethnobiology and Ethnomedicine), as well as in other biological areas (Alves et al. 2017; Fernandes-Ferreira et al. 2012). The publication of books in format of edited and qualified impact factor chapters (Alves and Rosa 2015), the creation of a publishing house that prints local production books (NUPEEA, http://www.nupeea.com), a master's degree postgraduate and doctorate in which ethnozoological themes are included (Programa de Pós Graduação em Etnobiologia e Conservação da Natureza, UFRPE) and recently the indexing of the journal Ethnobiology and Conservation at InCites Journal Citation Reports. 
Ethnobiology in general is a young science compared with others (Campos et al. 2016), while ethnozoology is seen as a recently created discipline (Alves 2012; Alves and Souto 2015; Lyra-Neves et al. 2015). Therefore, it is essential to generate academical spaces and workshops, where the conceptual and theoretical bases are taught, as well as the right methodologies for the collection of biological and ethnographic data, emphasizing its management and application (Albuquerque et al. 2014), also the integration of undergraduate and postgraduate students in order to generate new approaches and research questions (Albuquerque and Medeiros 2012; Sutherland et al. 2013). Arousing the interest in other sciences, such as conservation ecology, which currently considers ethnobiology, including implicitly ethnozoology, as a powerful tool to support the understanding of socio-environmental phenomena, which contribute to the conservation of ecosystems and their species (Albuquerque and Ferreira-Júnior 2017; Gavin et al. 2015; Huntington 2000; 2013; Saslis-Lagoudakis and Clarke 2013).

\section{CONCLUSIONS}

The meta-analytical approach identified a delay and a bias in mexican ethnozoological publishing, directly affecting its impact at a national and international level. The variables included within the analysis have allowed flows and trends evaluations. Identifying that, although there is no primary information homogeneization, it is possible to make a good data treatment, fulfilling some selection criteria and meta-analytical approach development in ethnozoology and ethnobiology.

Meta-analytical approach helped identifying information gaps at a theorical- methodological level, this phenomenon is possibly alike in other ethnobiological disciplines and at other scales. Identifying discipline's weaknesses is not a criticism but an evaluation, with the purpose of designing a reference frame to emit a series of recommendations. This allows a research structuration improvement in the different ethnobiological disciplines, specially ethnozoology, standardization in collecting, processing and analyzing ethnographic and biological data, as well as its publication which impacts nationally and internationally. With this, supporting the discipline consolidation and optimal development in future research.

Our research allowed to revaluate the primary information contribution, generating a new culture for doing ethnobiological research, by identifying patterns aren't possible at a local scale isolated or descriptively. Proposing its viability to understand socioecological systems, generating data which supports other disciplines, for example, conservation ecology, which is recently showing interest for human-ecosystem interactions in managing and designing biological conservation programs.

\section{FINAL CONSIDERATIONS}

\section{Recommendations for an ethnozoological work standardization}

In order to standardize the design, compilation, processing and analysis of data in the ethnobiological, and in particular, ethnozoological works, a series of general recommendations is issued. Considering basic principles in scientific research, ethnobiological methodological aspects, analysis of qualitative and quantitative data; as well as biological groups identification 
methods. These considerations should be applied to ensure the success, the right study execution and to give robustness to the collected data. Always paying attention to cultural peculiarities, so each researcher must select methods that meet their objectives better (Albuquerque et al. 2014).

1. Research question, goal and hypothesis. We must design questions that promote the ethnozoological discipline, more than the direct importance of the answer. Establishing an agenda in order to improve the general understanding of basic ethnobiology, as suggested in ecology (Sutherland et al. 2013). A research question or objective of undergraduate thesis, postgraduate thesis, research project or article, it is recommended to be punctual and not ambitious, as well as having the same level of ethnographic and biological contribution. The hypothesis must be designed a priori, and not a posteriori, considering that it is not always answered in a statistical way, but based on data (qualitative or quantitative). These research sections, are determinant for the ethnographic method design and selection, ethnographic tools, biological field methods and data analysis.

2. Study area selection: It must preferably be done under biological-ecological interest, socio-cultural interest (or both) criteria; avoiding choosing a study site under the researcher's preference criteria. Using maps (Geographic Information Systems, GIS), we analyze potential sites previously unstudied or associating them with certain conditions. Variables of interest are added such as vegetation types, vegetation cover, access paths, amount of inhabitants, native language speaker percentage, among others.

3. Ethnographic sample selection and informant types: We recommend to apply a combination of methods mentioned on specialized literature (Albuquerque et al. 2014; Bernard 2000; Martin 1995). Some suggestions for a qualitative approach are development under participatory research, joint and community action; this approach type is recommended when the goal is to work with key informants or at applied research, because it allows to get closer to the communities. The quantitative approach is based on selecting a representative sample, it can be statistical by using the minimum sample size (Cochran 1953). Using the percentage method, usually by randomly selecting $10 \%$ of the total of a population (Bernard 2000), or by applying the snowball technique, which is directed by the informants themselves (Berg 1983). In all cases we must have free, previous and informed consent; as well as recognizing and safeguarding the rights of ownership and custody of informants' knowledge (International Society of Ethnobiology 2006; http://ethnobiology.net/code-of-ethics/). We also propose to consider the informants as research collaborators depending on the level of confidence, this is common when working with key informants.

4. Ethnographic tools: are the interview types (structured, semi-structured, multiple free listing, etc.), observation and participative workshops, use of audio and video (Albuquerque et al. 2014; Alexiades 1996; Bernard 2000). Its design depends on the research question and the methodological approach, we recommend a tool combination in order to maximize data collection, as well as including all of the interest variables.

5. Databases: Designed in several types of software, and the number of fields depends on the variables and subvariables included within the ethnographic tools. They must be simple and make data management 
easy, based on matrix theory we can use binary code (presence, absence) as proposed in macroecology (Arita et al. 2008), or we can use ordinal matrix designs (Ryan et al. 2000). This matrix type can be designed in any spreadsheet software, with the advantage of organizing either qualitative and quantitative data. We also must consider data organization is related to applied ethnographic tools.

6. Data analysis: May include this analyses: a) ethnobiological, such as cultural importance and use value; b) statistical, descriptive, parametric, non-parametric and multivariate statistics; and c) ecological, richness and diversity indexes, species acumulation curve. Their application is right just as long as the data fulfill the theoretical assumptions of the chosen tests. This recommendations are for quantitative information analysis, while, for qualitative approach we suggest description, narrative, conceptual maps, graphical illustration, etc. Both data analysis approaches are valid and just as important in ethnobiology and ethnozoology.

7. Field biological methods: They directly depend on the biological group, due to this we recommend a field techniques review. Differentiating between sampling designs and monitoring techniques, random walks and transects are used in the designs in general. The techniques go specifical depending on the biological group, for example, direct search and visual encounters can be used for amphibians and reptiles, sightings for birds, and tracing footprints and excreta for mammals. We recommend to use simple and quick techniques and designs, which can be combined with ethnobiological tools such as the use of visual stimuli which are designed in previous reviews on the fauna diversity for the site. Another option is specimen photography, or parts of them in possession of the informants, as well as participatory observation.

\section{ACKNOWLEDGEMENTS}

T.V. Gutiérrez-Santillán received a scholarship (389096/254575) from CONACyT. To Oscar Gustavo RetanaGuiascón for review and recommendations to the manuscript.

\section{REFERENCES}

Adams DC (2008) Phylogenetic metaanalysis. Evolution 62(3): 567-572 doi:10.1111/j.1558-5646.2007.00314.x.

Albuquerque UP, Medeiros PM (2012) Systematic reviews and meta-analysis applied to ethnobiological research. Ethnobiology and Conservation 1(6): 1-8.

Albuquerque UP, Silva J, Campos J, Sousa R, Silva T, Alves RRN (2013) The current status of ethnobiological research in Latin America: gaps and perspectives. Journal of Ethnobiology and Ethnomedicine 9:72 doi:10.1186/1746-42699-72.

Albuquerque UP, Cunha L, Lucena RFP, Alves RRN (2014) Methods and techniques in ethnobiology and ethnoecology. 1ed. Springer, New York, USA doi:10.1007/978-1-4614-8636-7.

Albuquerque UP, Ferreira-Júnior W (2017) What do we study in evolutionary ethnobiology? Defining the theoretical basis for a research program. Evolutionary Biology 44(2): 206-215 doi:10.1007/s11692-016-9398-z.

Alcántara-Salinas G, Ellen R, Valiñas-Coalla L, Caballero J, Argueta-Villamar A (2013) Alternative ways of representing zapotec and cuicatec folk classification of birds: a multidimensional model and its implications for culturally-informed conservation in Oaxaca, Mexico. Journal of Ethnobiology and Ethnomedicine 9:81 doi:10.1186/1746-4269-981.

Alexiades MN (1996) Selected guidelines for ethnobotanical research: A field manual. 1 ed. Botanical Garden, New York, USA. 
Almazán-Catalán JA, Sánchez-Hernández C, Ruíz-Gutiérrez F, Romero-Almaraz ML, TaboadaSalgado A, Beltrán-Sánchez $E$, SánchezVázquez L (2013) Registros adicionales de felinos del estado de Guerrero, México. Revista Mexicana de Biodiversidad 84(1): 347359 doi:10.7550/rmb.23087.

Alonso-Castro AJ, Carranza-Álvarez C, Maldonado-Miranda JJ, Jacobo-Salcedo MR, Quezada-Rivera DA, Lorenzo-Márquez $H$, Figueroa-Zuñiga LA, Fernández-Galicia C, RíosReyes NA, León-Rubio MA, Rodríguez-Gallegos V, Medellín-Milán P (2011). Zootherapeutic practices in Aquismón, San Luis Potosí, Mexico. Journal of Ethnopharmacology 138(1): 233-237 doi:10.1016/j.jep.2011.09.020.

Alonso-Castro AJ (2014) Use of medicinal fauna in Mexican traditional medicine. Journal of Ethnopharmacology 152(1): 53-70 doi:10.1016/j.jep.2014.01.005.

ArchMiller AA, Bauer EF, Koch RE, Wijayawardena VK, Anil A, Kottwitz JJ, Munsterman AS, Wilson AE (2015) Formalizing the definition of meta-analysis in molecular ecology. Molecular Ecology 24(16): 4042-4051 doi:10.1111/mec.13264.

Alves RRN (2012) Relationships between fauna and people and the role of ethnozoology in animal conservation. Ethnobiology and Conservation 1(1): 1-69 doi:10.15451/ec2012-8-1.2-1-69.

Alves RRN, Rosa IL (2015) Animals in traditional folk medicine implications for conservation. Springer, Berlin doi:10.1007/9783-642-29026-8.

Alves RRN, Souto WMS (2015) Ethnozoology: a brief introduction. Ethnobiology and Conservation 4: 1-13 doi:10.15451/ec2015-1-4.11-13.

Alves R, Oliveira TPR, Medeiros MFT (2017) Trends in medicinal uses of edible wild vertebrates in Brazil. Evidence-Based Complementary and Alternative Medicine 4901329: 1-22 doi.org/10.1155/2017/4901329.

Amador-Alcalá S, Naranjo EJ, Jiménez-Ferrer G (2013) Wildlife predation on livestock and poultry: implications for predator conservation in the rainforest of south-east Mexico. Oryx 47(2): 243-250 doi:10.1017/S0030605311001359.

Arce-lbarra AM, Charles A (2008) Nonmanagement of natural resources: The case of inland fisheries in the mayan zone,
Quintana Roo, Mexico. Human Ecology 36(6): 853-860 doi:10.1007/s10745-008-9201-6.

Argueta-Villamar A, Corona-M E, AlcántaraSalinas G, Santos-Fita D, Aldasoro-Maya M, Serrano-Velázquez R, Teutli-Solano C, AstorgaDomínguez M (2012) Historia, situación actual y perspectivas de la etnozoología en México. Etnobiología 10(1): 18-40.

Arita $H$, Christen J, Rodríguez P, Soberón J (2008) Species diversity and distribution in presence absence matrices: mathematical relationships and biological implications. The American Naturalist 172(4): 519-532 doi:10.1086/590954.

Arnqvist G, Wooster D (1995) Meta-analysis: synthesizing research findings in ecology and evolution. Trends in Ecology \& Evolution 10(6): 236-40.

Ávila A (2008) La diversidad linguística y el conocimiento etnobiológico. In: Capital natural de México vol I: Conocimiento actual de la biodiversidad. Comisión Nacional para el Conocimiento y Uso de la Biodiversidad, México, pp. 497-556.

Ávila-Nájera DM, Rosas-Rosas OC, TarangoArámbula LA, Martínez-Montoya JF, SantoyoBrito E (2011) Conocimiento, uso y valor cultural de seis presas del jaguar (Panthera onca) y su relación con éste, en San Nicolás de los Montes, San Luis Potosí, México. Revista Mexicana de Biodiversidad 82: 10201028.

Barragán F, Retana OG, Naranjo EJ (2007) The rodent trade of tzeltal indians of Oxchuc, Chiapas, Mexico. Human Ecology 35(6): 769773 doi:10.1007/s10745-007-9116-7.

Basurto X, Cinti A, Bourillón L, Rojo M, Torre J, Weaver $\mathrm{AH}$ (2012) The emergence of access controls in small-scale fishing commons: a comparative analysis of individual licenses and common property-rights in two mexican communities. Human Ecology 40(4): 597-609 doi:10.1007/s10745-012-9508-1.

Berg S (1983) Random contact processes, snowball sampling and factorial series distributions. Applied Probability 20(1): 31-46 doi.org/10.1017/S002190020009690X.

Bernard HR (2000) Social research methods. 1ed. SAGE Publisher, California, USA.

Brand D (1962) Status of the ethnozoologic studies in Mesoamerica. Actas y Memorias del XXXV Congreso Internacional de Americanistas 3: 131-140. 
Bye R, Linares E (2000). Relationships between mexican ethnobotanical diversity and indigenous peoples. In: Minnis PE, Elisens WJ (eds) Biodiversity and Native America. University of Oklahoma, Oklahoma, pp. 44-73.

Caballero J, Casas A, Cortes L, Mapes C (1998) Patrones en el conocimiento, uso y manejo de plantas en pueblos indígenas de México. Estudios Atacameños 16: 181-195.

Campos A, Sobral A, Silva J, Araújo T, FerreiraJúnior W, Santoro F, Santos GC, Albuquerque UP (2016) Insularity and citation behavior of scientific articles in young fields: the case of ethnobiology. Scientometrics 109(2): 1037-1055 doi:10.1007/s11192-016-2067-2.

Cochran WG (1953) Sampling techniques. Oxford University, England.

Delfín-Alfonso CA, Hernández-Huerta $\mathrm{AH}$, Macías-Sánchez S, González-Gallina A, AlducinChávez G (2008) Adición a los registros de tapir centroamericano (Tapirus bairdii) en Oaxaca, México. Revista Mexicana de Biodiversidad 79(2): 535-538.

Eckert SL, Clark T (2009). The ritual importance of birds in 14th-century Central New Mexico. Journal of Ethnobiology 38(2): 827 doi:10.2993/0278-0771-29.1.8.

Egger M, Smith GD (1997) Meta-analysis: potentials and promise. British Medical Journal 315: 1371-1374.

Enríquez-Vázquez $P$, Mariaca-Méndez $R$, Retana-Guiascón OG, Naranjo-Pinera EJ (2006) Uso medicinal de la fauna silvestre en los Altos de Chiapas, México. Interciencia 31(7): 491-499.

ESRI (Environmental Systems Research Inc.) (1999) Arc View GIS Ver. 3.2. Environmental Systems Research, Inc. ESRI. New York, USA.

Fernandes-Ferreira $\mathrm{H}$, Mendonça S, Albano C, Ferreira F, Alves RRN (2012) Hunting, use and conservation of birds in Northeast Brazil. Biodiversity and Conservation 21(1): 221-244 doi:10.1007/s10531-011-0179-9.

Gallina S, Pérez-Torres J, Guzmán-Aguirre CC (2012) Use of the paca, Cuniculus paca (Rodentia: Agoutidae) in the Sierra de Tabasco State Park, Mexico. Revista de Biología Tropical 60(3): 1345-1355 doi:10.15517/rbt.v60i3.1812.
García-Alaniz N, Naranjo EJ, Mallory FF (2010) Human-felid interactions in three mestizo communities of the Selva Lacandona, Chiapas, Mexico: benefits, conflicts and traditional uses of species. Human Ecology 38(3): 454-457 doi:10.1007/s10745-010-9322-6.

García-del-Valle Y, Naranjo EJ, Caballero J, Martorell C, Ruan-Soto F, Enríquez, PL (2015) Cultural significance of wild mammals in mayan and mestizo communities of the Lacandon Rainforest, Chiapas, Mexico. Journal of Ethnobiology and Ethnomedicine 11:36 doi:10.1186/s13002-015-0021-7.

García-Grajales J (2013) El conflicto hombrecocodrilo en México: causas e implicaciones. Interciencia 38(12): 881-884.

Garibay-Orijel R, Caballero J, Estrada-Torres A, Cifuentes J (2007) Understanding cultural significance, the edible mushrooms case. Journal of Ethnobiology and Ethnomedicine 3:4 doi:10.1186/1746-4269-3-4.

Gates S (2002) Review of methodology of quantitative reviews using meta-analysis in ecology. Journal of Animal Ecology 71: 547-557.

Gavin MC, McCarter J, Mead A, Berkes F, Stepp JR, Peterson D, Tang R (2015) Defining biocultural approaches to conservation. Trends in Ecology \& Evolution 30(3): 140-145 doi:10.1016/j.tree.2014.12.005.

Google Earth

(2016)

https://www.google.com.mx/intl/es/earth/

Guerra-Roa M, Calmé S, Gallina-Tessaro S, Naranjo-Piñera EJ (eds) Uso y manejo de fauna silvestre en el norte de Mesoamérica. Gobierno del Estado de Veracruz - Instituto de Ecología - Colegio de la Frontera Sur, México.

Haemig PD (2010) Ecology and ethnobiology of the slender-billed grackle Quiscalus palustris. Journal of Ornithology 151(2): 391399 doi:10.1007/s10336-009-0467-2.

Haemig PD (2012) Introduction of the greattailed grackle (Quiscalus mexicanus) by Aztec emperor Ahuitzotl: provenance of the historical account. The Auk 135(4): 70-75 doi:10.1525/auk.2011.11058.

Haenn N, Schmook B, Reyes Y, Calmé S (2014) Improving conservation outcomes with insights from local experts and bureaucracies. Conservation Biology 28(4): 951-958 doi:10.1111/cobi.12265. 
Hammer $\varnothing$, Harper DAT, Ryan PD (2001) PAST: Paleontological statistics software package for education and data analysis. Palaeontologica Electronica doi:10.1017/CBO9781107415324.004.

Hunn E (2011) Ethnozoology. In: Anderson EN, Pearsall DM, Hunn E, Turner NJ (eds) Ethnobiology. Wiley-Blackwelll, New Jersey, pp. 83-96 doi:10.1017/CBO9781107415324.004.

Huntington HP (2000) Using traditional ecological knowledge in science: methods and applications. Ecological Applications 10(5): 1270-1274 doi:10.1890/10510761(2000)010[1270:UTEKIS]2.0.CO;2.

Huntington HP (2013) Local knowledge as a resource for Nepal: Building partnerships with scientists and conservationists. Conservation Science 1(1): 1-4 doi.org/10.3126/cs.v1i1.8577.

Ibarra JT, Barreau A, Campo C, Camacho Cl, Martin GJ, McCandless SR (2011) When formal and market-based conservation mechanisms disrupt food sovereignty: impacts of community conservation and payments for environmental services on an indigenous community of Oaxaca, Mexico. The Iternational Forestry Review 13(3): 318-337 doi:10.1505/ifor.11.2.155.

Inda-Díaz E, Rodiles-Hernández R, Naranjo EJ, Mendoza-Carranza M (2009) Subsistence fishing in two communities of the Lacandon Forest, Mexico. Fisheries Management and Ecology 16(3): 225-234 doi:10.1111/j.13652400.2009.00668.x.

International Society of Ethnobiology (2006). International Society of Ethnobiology Code of Ethics (with 2008 additions). http://ethnobiology.net/code-of-ethics/

Jacobo-Salcedo MR, Alonso-Castro AJ, ZarateMartínez A (2011) Folk medicinal use of fauna in Mapimi, Durango, Mexico. Journal of Ethnopharmacology 133(2): 902-906 doi:10.1016/j.jep.2010.10.005.

Jacobo-Salcedo MR, Juárez-Vázquez MC, González-Espíndola LA, Maciel-Torres SP, García-Carrancá A, Alonso-Castro AJ (2013) Biological effects of aqueous extract from turkey vulture Cathartes aura (Cathartidae) meat. Journal of Ethnopharmacology 145(2): 663-666 doi:10.1016/j.jep.2012.11.014.
Kampichler C, Calmé S, Weissenberger H, Arriaga-Weiss SL (2010) Indication of a species in an extinction vortex: the ocellated turkey on the Yucatan Peninsula, Mexico. Acta Oecologica 36(6): 561-568 doi: 10.1016/j.actao.2010.08.004.

Koricheva J, Gurevitch J (2014) Uses and misuses of meta-analysis in plant ecology. Journal of Ecology 102(4): 828-844 doi:10.1111/1365-2745.12224.

Kueffer C, Niinemets U, Drenovsky RE, Kattge J, Milberg P, Pooter $\mathrm{H}$, Reich PB, Werner C, Westoby M, Wright IJ (2011) Fame, glory and neglect in meta-analyses. Trends in Ecology \& Evolution 26(10): 493-494 doi:10.1016/j.tree.2011.07.007.

Ladle RJ, Todd PA, Malhado ACM (2012) Assessing insularity in global science. Scientometrics $\quad 93(3)$ : $\quad 745-750$ doi:10.1007/s11192-012-0703-z.

León P, Montiel S (2008) Wild meat use and traditional hunting practices in a rural mayan community of the Yucatan Peninsula, Mexico. Human Ecology 36(2): 249-257 doi:10.1007/s10745-007-9139-0.

Lira-Torres I, Galindo-Leal C, Briones-Salas M (2012) Mamíferos de la Selva Zoque, México: riqueza, uso y conservación. Revista de Biología Tropical 60(2): 781-797.

López-del-Toro P, Andresen E, Estrada A (2009) Attitudes and knowledge of shade-coffee farmers towards vertebrates and their ecological functions. Tropical Conservation Science 2(3): 299-318.

Lortie CJ (2014) Formalized synthesis opportunities for ecology: systematic reviews and meta-analyses. Oikos 123(8): 897-902 doi:10.1111/j.1600-0706.2013.00970.x.

Lortie CJ, Aarssen LW, Budden AE, Leimu R (2013) Do citations and impact factors relate to the real numbers in publications? A case study of citation rates, impact, and effect sizes in ecology and evolutionary biology. Scientometrics 94(2): 675-682 doi:10.1007/s11192-012-0822-6.

Lyra-Neves RM, Santos EM, Medeiros PM, Alves RRN, Albuquerque UP (2015) Ethnozoology in Brazil: analysis of the methodological risks in published studies. Brazilian Journal of Biology 75(4): 184-191 doi:10.1590/1519-6984.09314. 
Mancini A, Senko J, Borquez-Reyes R, GuzmánPóo J, Seminoff JA, Koch V (2011) To poach or not to poach an endangered species: elucidating the economic and social drivers behind illegal sea turtle hunting in Baja California Sur, Mexico. Human Ecology 39(6): 743-756 doi:10.1007/s10745-011-9425-8.

Martin GJ (1995) Ethnobotany, a methods manual. WWF International - UNESCO - Royal Botanical Garden, Kew, England.

Monroy-Vilchis O, Cabrera L, Suárez P, ZarcoGonzález MM, Rodríguez-Soto C, Urios V (2008) Uso tradicional de vertebrados silvestres en la sierra Nanchititla, México. Interciencia 33(4): 308-313.

Moreno-Fuentes A, Pulido-Silva MT, MariacaMéndez R, Valadez-Azúa $R$, Mejía-Correa $P$, Gutiérrez-Santillán TV (2010) Sistemas biocognitivos tradicionales, paradigmas en la conservación biológica y el fortalecimiento cultural. Asociación Etnobiológica Mexicana, A.C. - Global Diversity Foundation - El Colegio de la Frontera Sur - Universidad Autónoma del Estado de Hidalgo - Sociedad Latinoamericana de Etnobiología, D.F., México.

Naranjo EJ, Bodmer RE (2007) Source-sink systems and conservation of hunted ungulates in the Lacandon Forest, Mexico. Biological Conservation 138(3): 412-420 doi:10.1016/j.biocon.2007.05.010.

Oliva M, Montiel S, García A, Vidal L (2014) Local perceptions of wildlife use in Los Petenes Biosphere Reserve, Mexico: maya subsistence hunting in a conservation conflict context. Tropical Conservation Science 7(4): 781-795.

Phillips O, Gentry AH (1993a) The useful plants of Tambopata, Peru: I. Statistical hypothesis tests with a new quantitative technique. Economic Botany 47(1): 15-32 doi:10.1007/BF02862203.

Phillips O, Gentry AH (1993b) The useful plants of Tambopata, Peru: II. Additional hypothesis testing in quantitative ethnobotany. Economic Botany 47: 33-43.

Pieroni A (2001) Evaluation of the cultural significance of wild food botanicals traditionally consumed in Northwestern Tuscany, Italy. Journal of Ethnobiology 21(1): 89-104.
Pires S, Clarke RV (2012) Are parrots CRAVED? An analysis of parrot poaching in Mexico. Journal of Research in Crime and Delinquency $49(1)$ : $122-146$ doi:10.1177/0022427810397950.

Reyna-Hurtado R, Naranjo E, Chapman CA, Tanner GW (2009) Hunting and the conservation of a social ungulate: the whitelipped peccary Tayassu pecari in Calakmul, Mexico. Oryx 44(1): 89-96 doi:10.1017/S0030605309990664.

Reyna-Hurtado R, Tanner GW (2005) Habitat preferences of ungulates in hunted and non hunted areas in the Calakmul Forest, Campeche, Mexico. Biotropica 37(4): 676-685 doi:10.1111/j.1744-7429.2005.00086.x.

Reyna-Hurtado R, Tanner GW (2007) Ungulate relative abundance in hunted and non-hunted sites in Calakmul Forest (Southern Mexico). Biodiversity and Conservation 16(3): 743-756 doi:10.1007/s10531-005-6198-7.

Rodas-Trejo J, Romero-Berny El, Estrada A (2008) Distribution and conservation of the west indian manatee (Trichechus manatus manatus) in the Catazaja wetlands of northeast Chiapas, Mexico. Tropical Conservation Science 1(4): 321-333.

Rodríguez M, Montiel S, Cervera MD, Castillo MT, Naranjo EJ (2012) The practice and perception of batida (group hunting) in a maya community of Yucatan, Mexico. Journal of Ethnobiology 38(3): 212-227 doi:10.2993/0278-0771-32.2.212.

Romero-Balderas KG, Naranjo EJ, Morales HH, Nigh RB (2006) Daños ocasionados por vertebrados silvestres al cultivo de maíz en la Selva Lacandona, Chiapas, México. Interciencia 31(4): 276-283.

Ryan GW, Nolan JM, Yoder PS (2000) Successive free listing: using multiple free lists to generate explanatory models. Field Methods 12: 83-107.

Santos-Fita D, Argueta-Villamar A, AstorgaDomínguez M, Quiñones-Martínez M (2012a). La etnozoología en México: La producción bibliográfica del siglo XXI (2000-2011). Etnobiología 10(1): 41-51.

Santos-Fita D, Naranjo EJ, Rangel-Salazar JL (2012b) Wildlife uses and hunting patterns in rural communities of the Yucatan Peninsula, Mexico. Journal of Ethnobiology and Ethnomedicine 8:38 doi:10.1186/1746-4269-838. 
Santos-Fita D, Naranjo EJ, Estrada E, Mariaca $R$, Bello E (2015) Symbolism and ritual practices related to hunting in maya communities from central Quintana Roo, Mexico. Journal of Ethnobiology and Ethnomedicine 11:71 doi:10.1186/s13002-0150055-x.

Saslis-Lagoudakis CH, Clarke AC (2013) Ethnobiology: The missing link in ecology and evolution. Trends in Ecology \& Evolution 28(2): 67-68 doi:10.1016/j.tree.2012.10.017.

StatSoft Inc (2004) STATISTICA (Data Analysis Software System) versión 7, www.statoft.com.

Stewart G (2009) Meta-analysis in applied ecology. Biology Letters 6(1): 78-81 doi:10.1098/rsbl.2009.0546

Sutherland WJ, Freckleton RP, Godfray HCJ, Beissinger SR, Benton T, Cameron DD, Carmel Y, Coomes DA, Coulson T, Emmerson MC, Hails RS, Hays GC, Hodgson DJ, Hutchings MJ, Johnson D, Jones JPG, Keeling MJ, Kokko $H$, Kunin WE, Lambin $X$, Lewis OT, Malhi $Y$, Mieszkowska N, Milner-Gulland EJ, Norris K, Phillimore AB, Purves DW, Reid JM, Reuman DC, Thompson K, Travis JMJ, Turnbull LA, Wardle DA, Wiegand T (2013) Identification of 100 fundamental ecological questions. Journal of Ecology 101(1): 58-67 doi.org/10.1111/13652745.12025

Teixeira MC, Thomaz SM, Michelan TS, Mormul RP, Meurer T, Fasolli JV, Silveira MJ (2013) Incorrect citations give unfair credit to review authors in ecology journals. PlosOne 8(12): e81871 doi:10.1371/journal.pone.0081871.

Todd PA, Yeo DCJ, Li D, Ladle RJ (2007) Citing practices in ecology: can we believe our own words?. Oikos 116(9): 1599-1601 doi:10.1111/j.2007.0030-1299.15992.x.

Toledo VM, Barrera-Bassols N, García-Frapolli E, Alarcón-Cháires P (2008) Uso múltiple y biodiversidad entre los mayas yucatecos (México). Interciencia 33(5): 345-352.
Torres-Avilez W, Medeiros PM, Albuquerque UP (2016) Effect of gender on the knowledge of medicinal plants: systematic review and meta-analysis. Evidence-Based Complementary and Alternative Medicine 6592363: 1-13 doi:10.1155/2016/6592363.

Turner NJ (1988) The importance of a rose: evaluating the cultural significance of plants in Thompson and Lillooet Interior Salish. American Anthropologist 90(2): 272-290 doi:10.1525/aa.1988.90.2.02a00020.

Valdez R, Guzmán-Aranda JC, Abarca FJ, Tarango-Arámbula LA, Sánchez FC (2006) Wildlife conservation and management in Mexico. Wildlife Society Bulletin 34(2): 270-282.

Vázquez L-B, Gaston KJ (2006) People and mammals in Mexico: Conservation conflicts at a national scale. Biodiversity and Conservation 15(8): 2397-2414 doi:10.1007/s10531-004-3954Z.

Vásquez-Dávila MA (2014) Aves, personas y culturas: Estudios de etno-ornitología 1. CONACYT - ITVO - Carteles Editores - UTCH, Oaxaca, México.

Weber M, García-Marmolejo G, Reyna-Hurtado $\mathrm{R}$ (2006) The tragedy of the commons: wildlife management units in southeastern Mexico. Wildlife Society Bulletin 34(5): 1480-1488.

Zamudio F, Bello-Baltazar E, Estrada-Lugo E (2013) Learning to hunt crocodiles: social organization in the process of knowledge generation and the emergence of management practices among mayan of Mexico. Journal of Ethnobiology and Ethnomedicine 9:35 doi:10.1186/1746-4269-935.

Zar JH (2010) Biostatistical analysis fifth edition. Pearson Education Upper Saddie River, New Jersey, USA.

Received: 25 June 2018

Accepted: 06 November 2018

Published: 28 November 2018 


\section{Suplementary Material (Revised studies)}

Acuca-Vázquez D, Alcántara-Salinas G, Valiñas-Coalla L, Ellen RF, Escalante-Pliego P, Babb-Stanley, Argueta-Villamar A (2014) La etnoclasificación de las aves de los zapotecos Del Rincón, Oaxaca, México. In: Vásquez-Dávila MA (ed) Aves, personas y culturas Estudios de etno-ornitología 1. CONACYT - ITVO - Carteles Editores - UTCH, Oaxaca, pp. 207-227.

Alarcón-Cháires P (2009) Etnoecología de los indígenas p'urhépecha. Una guía para el análisis de la apropiación de la naturaleza. Universidad Nacional Autónoma de México, Michoacán, México.

Alcalá J, Soto R, Lebgue T, Sosa M (2007) Percepción comunitaria de la flora y fauna urbana en la ciudad de Chihuahua, México. Revista Latinoamericana de Recursos Naturales 3(1): 58-64.

Alcántara-Salinas G (2011) A comparative study of cuicatec and zapotec Ethno-ornithology, with particular reference to contextual variation in a time of environmental and social change in Oaxaca, Mexico. PhD Thesis, University of Kent, Canterbury, United Kingdom.

Alcántara-Salinas G, Ellen R, Valiñas-Coalla L, Caballero J, Argueta-Villamar A (2013) Alternative ways of representing zapotec and cuicatec folk classification of birds: a multidimensional model and its implications for culturally-informed conservation in Oaxaca, Mexico. Journal of Ethnobiology and Ethnomedicine 9:81 doi:10.1186/1746-4269-9-81.

Aldasoro-Maya M (2012) Documenting and contextualizing pjiekakjoo (tlahuica) knowledges through a collaborative research project. PhD Thesis, University of Washington, Washington, USA.

Alfaro-Martínez M (2014) Uso de la vida silvestre. In: La biodiversidad en Chihuahua: Estudio de Estado. Comisión Nacional para el Conocimiento y Uso de la Biodiversidad, México, pp. 164-167.

Almazán-Catalán JA, Sánchez-Hernández C, Ruíz-Gutiérrez F, Romero-Almaraz ML, Taboada-Salgado A, Beltrán-Sánchez E, Sánchez-Vázquez L (2013) Registros adicionales de felinos del estado de Guerrero, México. Revista Mexicana de Biodiversidad 84(1): 347-359 doi:10.7550/rmb.23087.

Alonso-Castro AJ, Carranza-Álvarez C, Maldonado-Miranda JJ, Jacobo-Salcedo MR, Quezada-Rivera DA, Lorenzo-Márquez H, Figueroa-Zuñiga LA, Fernández-Galicia C, Ríos-Reyes NA, León-Rubio MA, Rodríguez-Gallegos V, Medellín-Milán P (2011). Zootherapeutic practices in Aquismón, San Luis Potosí, Mexico. Journal of Ethnopharmacology 138(1): 233-237 doi:10.1016/j.jep.2011.09.020

Alonso-Castro AJ (2014) Use of medicinal fauna in Mexican traditional medicine. Journal of Ethnopharmacology 152(1): 53-70 doi:10.1016/j.jep.2014.01.005.

Alonso-García JM (2011) Contribución al conocimiento etnozoológico de los vertebrados acuáticos de la laguna de Tecocomulco, Hidalgo, México. Undergraduate thesis, Universidad Nacional Autónoma de México, D.F., México.

Amador-Alcalá S, Naranjo EJ, Jiménez-Ferrer G (2013) Wildlife predation on livestock and poultry: implications for predator conservation in the rainforest of south-east Mexico. Oryx 47(2): 243-250 doi:10.1017/S0030605311001359.

Anderson EN (2010) Food and feasting in the zona maya of Quintana Roo. In: Staller JE, Carrasco MD (eds) Pre-Columbian foodways: Interdisciplinary approaches to food, culture, and markets in ancient Mesoamerica. Springer, doi:10.1007/978-14419-0471-3_18.

Arce-lbarra AM, Charles A (2008) Non-management of natural resources: The case of inland fisheries in the mayan zone, Quintana Roo, Mexico. Human Ecology 36(6): 853-860 doi:10.1007/s10745-008-9201-6.

Argueta-Villamar A (2008) Los saberes p'urhépecha los animales y el diálogo con la naturaleza. Universidad Michoacana de San Nicolás de Hidalgo - Universidad Nacional Autónoma de México - Gobierno del Estado de Michoacán - Universidad Intercultural Indígena de Michoacán - Casa Juan Pablos - Programa de Naciones Unidas para el Medio Ambiente, D.F., México.

Argueta-Villamar A, Corona-M E, Alcántara-Salinas G, Santos-Fita D, Aldasoro-Maya M, Serrano-Velázquez R, Teutli-Solano C, Astorga-Domínguez M (2012) Historia, situación actual y perspectivas de la etnozoología en México. Etnobiología 10(1): 18-40.

Arias TE (2007) El cocodrilo en la región maya Yokot'an: Un acercamiento antropológico a la actualidad del ambiente en Tabasco. Itinerarios 6: 101-122.

Arias-Reyes LM, Montiel-Ortega S (2010) Campesinos-pescadores de Yucatán: uso de la biodiversidad y apropiación de recursos naturales costeros. Revista de Geografía Agrícola, Estudios Regionales de la Agricultura Mexicana 25-40. 
Astorga-Domínguez M (2012) Etnobiología de la comunidad de Cahuitán, Oaxaca, México. MSc. dissertation, Universidad Autónoma de Ciudad Juárez, Cd. Juárez, México.

Ávila-Nájera DM, Rosas-Rosas OC, Tarango-Arámbula LA, Martínez-Montoya JF, Santoyo-Brito E (2011) Conocimiento, uso y valor cultural de seis presas del jaguar (Panthera onca) y su relación con éste, en San Nicolás de los Montes, San Luis Potosí, México. Revista Mexicana de Biodiversidad 82: 1020-1028.

Barragán F, Retana OG, Naranjo EJ (2007) The rodent trade of tzeltal indians of Oxchuc, Chiapas, Mexico. Human Ecology 35(6): 769-773 doi:10.1007/s10745-007-9116-7.

Barrasa-García S (2012) Conocimiento y usos tradicionales de la fauna en dos comunidades campesinas de la reserva de Biosfera de la Encrucijada, Chiapas. Etnobiología 10(1): 16-28.

Barrera-Bassols N, Toledo VM (2005) Ethnoecology of the yucatec maya: symbolism, knowledge and management of natural resources. Journal of Latin American Geography 4(1): 9-41.

Basurto X, Cinti A, Bourillón L, Rojo M, Torre J, Weaver AH (2012) The emergence of access controls in small-scale fishing commons: a comparative analysis of individual licenses and common property-rights in two mexican communities. Human Ecology 40(4): 597-609 doi:10.1007/s10745-012-9508-1.

Beauregard-Solís G, Magaña-Alejandro MA, Cámara-Córdoba J (2005) La cultural del jaguar. Kuxulkab’ 19-29.

Beauregard-Solís G, Zenteno-Ruiz CE, Armijo-Torres R, Guzmán-Juárez E (2010) Las tortugas de agua dulce: patrimonio zoológico y cultural de Tabasco. Kuxulkab' 5-20.

Benavides-Rosales A (2009) El impacto de Flamingo Lakes en el patrimonio cultural y natural de la región de Xcambó, Yucatán. MSc. dissertation, Centro de Investigación y de Estudios Avanzados del Instituto Politécnico Nacional, Mérida, México.

Berlanga H, Kennedy JA, Rich TD, Arizmendi MC, Beardmore CJ, Blancher PJ, et al. (2010). Conservando a nuestras aves compartidas: la visión trinacional de compañeros en vuelo para la conservación de las aves terrestres. Cornell Lab of Ornithology, New York, USA.

Blanco A, Pérez G, Rodríguez B, Sugiyama N, Torres F, Valadez R (2009) El zoológico de Moctezuma ¿Mito o realidad?. AMMVEPE 20(2): 28-39.

Bravo-Marentes C, Neyra-González L (2009) Recursos biológicos de uso artesanal. In: Cruz-Murueta M, López-Binnqüist C, Neyra-González L (eds) Artesanías y Medio Ambiente. Comisión Nacional para el Conocimiento y Uso de la Biodiversidad, México, pp. 55-101.

Briceño-Méndez MA, Montes-Pérez R, Aguilar-Cordero W, Pool-Cruz A (2011) Cacería del pecarí de collar (Pecari tajacu) (Artiodactyla: Tayassuidae) en Tzucacab, Yucatán, México. Revista Mexicana de Mastozoología. Nueva Época 1(1): 8-18.

Brindis-Badillo DA (2010) Mamíferos medianos y grandes de Palo Grande, municipio de Miacatlán, Estado de Morelos. Undergraduate thesis, Universidad Nacional Autónoma de México, D.F., México.

Brown CH (2010) Raven-Heron in mayan language prehistory: an ethno-ornithological/linguistic study. In: Tidemann S, Gosler A (eds) Ethno-ornithology: birds, indigenous peoples, culture and society. Earthscan, London, doi:10.4324/9781849774758.

Calderón-Mandujano RR (2008) Conocimiento y uso de la tortuga blanca (Dermatemys mawii Gray, 1847) en diez ejidos en el sur de Quintana Roo, México. Etnobiología 6: 42-55.

Calmé S (2011) Uso y manejo de fauna silvestre. In: Pozo C, Armijo-Canto N, Calmé S (eds) Riqueza biológica de Quintana Roo: un análisis para su conservación. El Colegio de la Frontera Sur - Comisión Nacional para el Conocimiento y Uso de la Biodiversidad - Gobierno del Estado de Quintana Roo - Programa de Pequeñas Donaciones, México, pp. 165-170.

Calmé S, Sanvicente M (2009) Distribución, uso de hábitat y amenazas para la nutria neotropical (Lontra longicaudis annectens): un enfoque etnozoológico. In: Espinosa-Ávalos J, Hernández-Arana IHA (eds) El sistema ecológico de La Bahía de Chetumal/Corozal: costa occidental del Mar Caribe. El Colegio de la Frontera Sur, México, pp. 123-130.

Camacho-Escobar MA, Jiménez-Hidalgo E, Sánchez-Bernal El, Pérez-Lara E (2011) Historia natural, domesticación y distribución del guajolote (Meleagris gallopavo) en México. Universidad y Ciencia 27(3): 351-360.

Camacho-Escobar MA, Vásquez-Dávila MA, Kollas JC, Núñez-García RM, Sánchez-Bernal El, Ávila-Serrano NY, ArroyoLedezma J (2014) Crax rubra y otras aves silvestres en la Sierra Norte de Oaxaca, México. In: Vásquez-Dávila MA (ed) Aves, personas y culturas Estudios de etno-ornitología 1. CONACYT - ITVO - Carteles Editores - UTCH, Oaxaca, pp. 229-241. 
Cano-Contreras EJ (2007) Prácticas y procesos simbólicos de las mordeduras de serpiente entre los lacandones de Nahá, Chiapas, México. MSc. dissertation, El Colegio de la Frontera Sur San Cristóbal de Las Casas, México.

Cárdenas-Aquino MR, Gómez-Álvarez G, Reyes-Gómez SR (2010) Las aves descritas en la obra de Francisco Hernández, Historia natural de Nueva España, su situación actual y análisis de los nombres nahuas, México. In: Moreno-Fuentes A, PulidoSilva MT, Mariaca-Méndez R, Valadez-Azúa R, Mejía-Correa P, Gutiérrez-Santillán TV (eds) Sistemas biocognitivos tradicionales, paradigmas en la conservación biológica y el fortalecimiento cultural. Asociación Etnobiológica Mexicana A.C. Global Diversity Foundation - El Colegio de la Frontera Sur - Universidad Autónoma del Estado de Hidalgo - Sociedad Latinoamericana de Etnobiología, D.F., pp. 403-414.

Casanova E, Mazó L, Quiroz J, Rodríguez G, Soto R (2015) Inventario preliminar de los animales locales utilizados en la gastronomía de la Chontalpa en Tabasco, México. Actas Iberoamericanas de Conservación Animal 6: 201-211.

Casas-Andreu G (2005) Anfibios, reptiles y otros animales de la Expedición Malaspina (1789-1794) en Nueva España, un capítulo inédito de la Zoología Mexicana. Revista de la Sociedad Mexicana de Historia Natural 3a Época 2(1): 246-250.

Casas-Andreu G (2009) Contribuciones para la historia del conocimiento de los cocodrilos en México. Revista Latinoamericana de Conservación 1(2): 17-24.

Cedeño-Vázquez JR (2011) El cocodrilo recurso milenario. In: Pozo C, Armijo-Canto N, Calmé S (eds) Riqueza biológica de Quintana Roo. Un análisis para su conservación. El Colegio de la Frontera Sur - Comisión Nacional para el Conocimiento y Uso de la Biodiversidad - Gobierno del Estado de Quintana Roo - Programa de Pequeñas Donaciones, México, pp. 234-240.

Centeno-Pérez VA, Arriaga-Weiss SL (2010) Uso y aprovechamiento de fauna silvestre en comunidades del Parque Estatal de La Sierra, Tabasco, México. In: Guerra-Roa M, Calmé S, Gallina-Tessaro S, Naranjo-Piñera EJ (eds) Uso y manejo de fauna silvestre en el norte de Mesoamérica. Gobierno del Estado de Veracruz - Instituto de Ecología - Colegio de la Frontera Sur, México, pp. 53-77.

Chablé-Santos J, Delfín-González H (2010) Uso tradicional de fauna silvestre. In: Durán R, Méndez M (eds) Biodiversidad y desarrollo humano en Yucatán. CICY - PPD-FMAM - CONABIO - SEDUMA, México, pp. 377-381.

Chamoreau C, Argueta-Villamar A (2011) Lo animado y lo inanimado entre los p'urhépecha de Michoacán. In: Pitrou P, Valverde-Valdés MC, Neurath J (eds) La noción de la vida en Mesoamérica. CEMCA - UNAM, México, pp. 95-117.

Chávez-Ruíz JA, Gómez-Álvarez G (2010) Uso tradicional de los vertebrados terrestres en dos comunidades zapotecas del Istmo de Tehuantepec, Oaxaca, México. In: Moreno-Fuentes A, Pulido-Silva MT, Mariaca-Méndez R, Valadez-Azúa R, MejíaCorrea P, Gutiérrez-Santillán TV (eds) Sistemas biocognitivos tradicionales, paradigmas en la conservación biológica y el fortalecimiento cultural. Asociación Etnobiológica Mexicana A.C. - Global Diversity Foundation - El Colegio de la Frontera Sur Universidad Autónoma del Estado de Hidalgo - Sociedad Latinoamericana de Etnobiología, D.F., pp. 232-238.

Contreras-Balderas AJ, García-Salas JA (2011) Etnobiología: importancia de las aves en la medicina tradicional precolombiana. Entorno Universitario 34: 6-8.

Contreras-Díaz RG, Pérez-Lustre M (2010) Conocimiento y uso mastofaunístico en una región de la Chinantla alta de Oaxaca, México. In: Moreno-Fuentes A, Pulido-Silva MT, Mariaca-Méndez R, Valadez-Azúa R, Mejía-Correa P, Gutiérrez-Santillán TV (eds) Sistemas biocognitivos tradicionales, paradigmas en la conservación biológica y el fortalecimiento cultural. Asociación Etnobiológica Mexicana A.C. - Global Diversity Foundation - El Colegio de la Frontera Sur - Universidad Autónoma del Estado de Hidalgo - Sociedad Latinoamericana de Etnobiología, D.F., pp. 452-252.

Contreras-Moreno FM, Cruz-Félix K, Bello-Gutiérrez J (2012) Uso patrones de cacería y preferencia de presas en dos sitios del Parque Estatal La Sierra, Tabasco, México. Etnobiología 10(3): 1-9.

Corona-M E (2011) Apuntes sobre las relaciones hombre-fauna, como un escenario del diálogo de saberes. In: ArguetaVillamar A, Corona-M E, Hersch-Martínez P (eds) Saberes colectivos y diálogo de saberes en México. Universidad Nacional Autónoma de México, D.F., pp. 121-134.

Corona-Zárate P, Gallina-Tessaro S, Contreras-Hernández A (2010) Aprovechamiento del venado cola blanca en una UMA de la Sierra de Huautla, Morelos. In: Uso y manejo de fauna silvestre en el norte de Mesoamérica. Gobierno del Estado de Veracruz - Instituto de Ecología - Colegio de la Frontera Sur, México, pp. 263-296.

Cortés-Gregorio I, Pascual-Ramos E, Medina-Torres SM, Sandoval-Forero EA, Lara-Ponce E, Piña-Ruíz HH, Martínez-Ruíz R, Rojo-Martínez GE (2013) Etnozoología del pueblo mayo-yoreme en el norte de Sinaloa: uso de vertebrados silvestres. Agricultura, Sociedad y Desarrollo 10(3): 335-358. 
Cossío-Bayúgar A (2007) Conocimiento y comparación del uso de la fauna silvestre en dos comunidades ejidales del municipio de Hueytamalco, Puebla, México. MSc. dissertation, Instituto de Ecología, Xalapa, México.

Cossío-Bayúgar A, González-Romero A, Sosa-Fernández V, Nigh-Nielsen R (2010) Diagnóstico de la organización comunitaria para el uso de fauna silvestre en dos comunidades ejidales del municipio de Hueytamalco, Puebla, México. In: Guerra-Roa M, Calmé S, Gallina-Tessaro S, Naranjo-Piñera EJ (eds) Uso y manejo de fauna silvestre en el norte de Mesoamérica. Gobierno del Estado de Veracruz - Instituto de Ecología - Colegio de la Frontera Sur, México, pp. 381-421.

Coutiño-Molina J (2010) Abundancia relativa de un ensamble de zopilotes (Falconiformes) y su relación con las comunidades humanas en la Reserva de la Biosfera El Ocote, Chiapas. MSc. dissertation, El Colegio de la Frontera Sur, San Cristóbal de Las Casas, México.

Cruz F, Vásquez-Dávila MA, Jerez-Salas MP, Montaño-Contreras EA, Villegas-Aparicio Y (2014) Aves silvestres y domesticadas de los chontales de San Andrés Tlahuilotepec, Distrito de Yautepec, Oaxaca, México. In: Vásquez-Dávila MA (ed) Aves, personas y culturas Estudios de etno-ornitología 1. CONACYT - ITVO - Carteles Editores - UTCH, Oaxaca, pp. 169186.

Cruz-Félix HK, Bello-Gutiérrez J (2008) Patrones de cacería en dos sierras con diferente grado de conservación en el Parque Estatal de la Sierra, Tabasco. In: Sánchez AJ, Hidalgo-Mihart MG, Contreras-Sánchez WM (eds) Perspectivas en zoología mexicana. Universidad Juárez Autónoma de Tabasco, México, pp. 217-234.

Cruz-Hernández VM (2013) El ajolote (Ambystoma velasci) en el ejido de San Miguel Allende, Tecocomulco, Hidalgo: etnozoología y datos de la biología alimentaria. Undergraduate thesis, Universidad Nacional Autónoma de México, D.F., México.

Cruz-Jacinto MA, Vásquez-Dávila MA, García-Marín PC, Jerez-Salas MP (2014) Aspectos etnoecológicos de la ornitofauna entre los ikoot de San Mateo del Mar, Oaxaca, México. In: Vásquez-Dávila MA (ed) Aves, personas y culturas Estudios de etnoornitología 1. CONACYT - ITVO - Carteles Editores - UTCH, Oaxaca, pp. 151-167.

Cruz-Mass GA (2010) Actividad cinegética y aprovechamiento de la fauna silvestre en la comunidad maya de Nunkiní, Campeche, México. Undergraduate thesis, Universidad Autónoma de Campeche, Campeche, México.

Cuautle-Hernández E, Yanes-Gómez G (2010) Percepción local de la actividad del murciélago hematófago Desmodus rotundus en el municipio de Santa Inés Ahuatempan, Puebla, México. In: Moreno-Fuentes A, Pulido-Silva MT, Mariaca-Méndez R, Valadez-Azúa R, Mejía-Correa P, Gutiérrez-Santillán TV (eds) Sistemas biocognitivos tradicionales, paradigmas en la conservación biológica y el fortalecimiento cultural. Asociación Etnobiológica Mexicana A.C. - Global Diversity Foundation - El Colegio de la Frontera Sur - Universidad Autónoma del Estado de Hidalgo - Sociedad Latinoamericana de Etnobiología, D.F., pp. 64-72.

Cupul-Magaña FG, Rubio-Delgado A, Reyes-Juárez A (2005) La mordida del cocodrilo americano (Crocodylus acutus) ¿es potencialmente séptica?. Revista Biomédica 16(203): 65-67.

Dardón-Espadas R (2011) Uso medicinal de la fauna silvestre por comunidades mayas en la región de los Chenes, Campeche, México. Undergraduate thesis, Universidad Autónoma de Campeche, Campeche, México.

Dávila-Sotelo JP (2012) Aprovechamiento de las aves acuáticas silvestres por la comunidad de San Miguel Allende, municipio de Tepeapulco, Hidalgo. Undergraduate thesis, Universidad Nacional Autónoma de México, D.F., México.

Delfín-Alfonso CA, Hernández-Huerta AH, Macías-Sánchez S, González-Gallina A, Alducin-Chávez G (2008) Adición a los registros de tapir centroamericano (Tapirus bairdii) en Oaxaca, México. Revista Mexicana de Biodiversidad 79(2): 535-538.

Díaz-Hernández H (2013) Evaluación del hábitat del venado cola blanca (Odocoileus virginianus mexicanus) en cuatro unidades de manejo para la conservación de la vida silvestre de la Mixteca Poblana. MSc. dissertation, Colegio de Posgraduados, Puebla, México.

Eccardi $F$ (2008) El águila real, simbolismo de la identidad mexicana. Biodiversitas 7: 1-6.

Eckert SL, Clark T (2009). The ritual importance of birds in 14th-century Central New Mexico. Journal of Ethnobiology 38(2): 827 doi:10.2993/0278-0771-29.1.8.

Enríquez-Vázquez P, Mariaca-Méndez R, Retana-Guiascón OG, Naranjo-Pinera EJ (2006) Uso medicinal de la fauna silvestre en los Altos de Chiapas, México. Interciencia 31(7): 491-499.

Escalante-Vargas M, Trejo-Pérez JL (2014) Aves silvestres criadas en cautiverio en Huapacal Segunda Sección, Jalpa de Méndez, Tabasco, México. In: Vásquez-Dávila MA (ed) Aves, personas y culturas Estudios de etno-ornitología 1. CONACYT ITVO - Carteles Editores - UTCH, Oaxaca, pp. 59-69. 
Escobedo-Cabrera E (2011) Mamíferos terrestres. In: Pozo C, Armijo-Canto N, Calmé S (eds) Riqueza biológica de Quintana Roo: un análisis para su conservación. El Colegio de la Frontera Sur - Comisión Nacional para el Conocimiento y Uso de la Biodiversidad - Gobierno del Estado de Quintana Roo - Programa de Pequeñas Donaciones, México, pp. 267-271.

Estrada A, Saenz J, Harvey C, Naranjo E, Muñoz D, Rosales-Meda M (2005) Primates in agroecosystems: conservation value of some agricultural practices in Mesoamerican landscapes. In: Estrada A, Garber PA, Pavella MSM, Luecke L (eds) New perspectives in the study of Mesoamerican primates: distribution, ecology, behavior, and conservation. Springer, New York, pp. 437-470.

Estrada-Lugo EIJ, Arce-lbarra AM (2011) La pesca entre los mayas macehuales del centro de Quintana Roo: organización social y conocimiento local. In: Bello-Baltazar E, Estrada-Lugo EIJ (eds) Cultivar el territorio maya conocimiento y organización social en el uso de la selva. Universidad Iberoamericana - RedISA - El Colegio de la Frontera Sur, México, pp. 189-211.

Fernández-Badillo L (2008) Anfibios y reptiles del Alto Mezquital, Hidalgo. Undergraduate thesis, Universidad Nacional Autónoma de México, D.F. México.

Flores-Manzanero A, González-Pérez GE, Vásquez-Dávila MA, Manzanero-Medina GI (2013) Conocimiento y usos de Odocoileus virginianus en Santo Domingo Tonalá, Oaxaca. Therya 4(1): 103-112 doi:10.12933/therya-13-92.

Frías-Ovando LM, Magaña-Alejandro MA (2014) Uso tradicional del zopilote negro (Coragyps atratus) en dos rancherías de Nacajuca, Tabasco, México. In: Vásquez-Dávila MA (ed) Aves, personas y culturas Estudios de etno-ornitología 1. CONACYT ITVO - Carteles Editores - UTCH, Oaxaca, pp. 53-58.

Galindo-Aguilar RE (2012) Conocimiento tradicional y usos de los mamíferos terrestres silvestres en dos localidades indígenas del bosque tropical lluvioso del norte de Oaxaca, México. Undergraduate thesis, Universidad Nacional Autónoma de México, D.F. México.

Gallegos-Peña A, Bello-Gutiérrez J, De-la-Cruz AJ (2010) Cuantificación del daño ocasionado por mamíferos terrestres a cultivos de maíz en el ejido Oxolotán del municipio de Tacotalpa, Tabasco, México. In: Guerra-Roa M, Calmé S, GallinaTessaro S, Naranjo-Piñera EJ (eds) Uso y manejo de fauna silvestre en el norte de Mesoamérica. Gobierno del Estado de Veracruz - Instituto de Ecología - Colegio de la Frontera Sur, México, pp. 297-313.

Gallina S, Pérez-Torres J, Guzmán-Aguirre CC (2012) Use of the paca, Cuniculus paca (Rodentia: Agoutidae) in the Sierra de Tabasco State Park, Mexico. Revista de Biología Tropical 60(3): 1345-1355 doi:10.15517/rbt.v60i3.1812.

García-Alaniz N, Naranjo EJ, Mallory FF (2010) Human-felid interactions in three mestizo communities of the Selva Lacandona, Chiapas, Mexico: benefits, conflicts and traditional uses of species. Human Ecology 38(3): 454-457 doi:10.1007/s10745-0109322-6.

García-del-Valle Y, Naranjo EJ, Caballero J, Martorell C, Ruan-Soto F, Enríquez, PL (2015) Cultural significance of wild mammals in mayan and mestizo communities of the Lacandon Rainforest, Chiapas, Mexico. Journal of Ethnobiology and Ethnomedicine 11:36 doi:10.1186/s13002-015-0021-7.

García-Flores A, Lozano-García MA, Ortiz-Villaseñor AL, Monroy-Martínez R (2014) Uso de mamíferos silvestres por habitantes del Parque Nacional El Tepozteco, Morelos, México. Etnobiología 12(3): 57-66.

García-Grajales J (2013) El conflicto hombre-cocodrilo en México: causas e implicaciones. Interciencia 38(12): 881-884.

García-Grajales J, Buenrostro-Silva A (2015a) Apreciación local acerca del cocodrilo americano (Crocodylus acutus) en comunidades rurales del Parque Nacional Lagunas de Chacahua, (Oaxaca, México). Etnobiología 13(1): 73-80.

García-Grajales J, Buenrostro-Silva A (2015b) Áreas de interacción entre humanos y cocodrilos (Crocodylus acutus Cuvier) en Chachahua, Oaxaca, México. Agroproductividad 8(5): 25-33.

García-Grajales J, Contreras-Hernández A, Aguirre-León G (2010) Diseño de una estrategia de manejo del cocodrilo de río en el estero La Ventanilla, Oaxaca, México. In: Guerra-Roa M, Calmé S, Gallina-Tessaro S, Naranjo-Piñera EJ (eds) Uso y manejo de fauna silvestre en el norte de Mesoamérica. Gobierno del Estado de Veracruz - Instituto de Ecología - Colegio de la Frontera Sur, México, pp. 161-192.

Gatica-Colima A, Jiménez-Castro JA (2009) Serpientes de cascabel: percepción por algunos pobladores del desierto chihuahuense en el estado Chihuahua. Revista Latinoamericana de Recursos Naturales 5(3): 198-204.

Gómez-Álvarez G, Teutli-Solano C, Reyes-Gómez SR, Valadez-Azúa R (2005) Pájaros y otras aves utilizados como animales de ornato y compañía. AMMVEPE 16(5): 129-139. 
Gómez-Álvarez G, Valadez-Azúa R, Teutli-Solano C, Reyes-Gómez SR (2005) Manejo en cautiverio de psitácidos utilizados como aves de ornato y compañía. AMMVEPE 16(1): 5-17.

Gómez-Álvarez G, Reyes-Gómez SR, Valadez-Azúa R (2006) Falconiformes mexicanas, comercio y uso en la cetrería. AMMVEPE 17(6): 245-254.

Gómez-Álvarez G, Reyes-Gómez SR, Teutli-Solano C, Valadez-Azúa R (2007) La medicina tradicional prehispánica, vertebrados terrestres y productos medicinales de tres mercados del Valle de México. Etnobiología 5: 86-98.

Gómez-Álvarez G, Reyes-Gómez SR, León-Pérez J (2009) Fauna silvestre de la Malinche: importancia cultural y utilitaria. In: Castro-Pérez F, Tucker TM (eds) Matlalcuéyetl: visiones plurales sobre cultura, ambiente y desarrollo. El Colegio de Tlaxcala A.C. - CONACYT - Mesoamerican Research Foundation, México, pp. 173-190.

Gómez-Álvarez G, Pacheco-Coronel N (2010) Uso medicinal de serpientes comercializadas en dos mercados de la ciudad de México. Etnobiología 8: 51-58.

Gómez-Álvarez G, Reyes-Gómez SR (2010) Colibríes comercializados como productos medicinales en el Distrito Federal, México. El Canto del Cenzontle I(1): 103-108.

González-Bocanegra K, Romero-Berny El, Escobar-Ocampo MC, García-del-Valle Y (2011) Aprovechamiento de fauna silvestre por comunidades rurales en los humedales de Catazajá-La Libertad, Chiapas, México. Ra Ximhai 7(2): 219-230.

González-Hernández CM (2008) Diagnóstico del funcionamiento de las unidades para la conservación, manejo y aprovechamiento de la vida silvestre (UMA), que trabajan con fauna silvestre en el Estado de Chiapas. Undergraduate thesis, Universidad de Ciencias y Artes de Chiapas, Tuxtla Gutiérrez, México.

González-Pérez D (2013) De naguales y culebras. Entidades sobrenaturales y "guardianes de los pueblos" en el sur de Oaxaca. Anales de Antropología 47(I): 31-55.

González-Romo CE, Garza-Torres HA, Padrón-Serrano E, Jiménez-Ramírez R, Berrones-Benítez E (2014) Las aves de El Cielo: Etnobiología y observaciones de la naturaleza para su conservación en una área natural protegida de Tamaulipas, México. In: Vásquez-Dávila MA (ed) Aves, personas y culturas Estudios de etno-ornitología 1. CONACYT - ITVO - Carteles Editores - UTCH, Oaxaca, pp. 261-283.

González-Sierra ER (2011) Desarrollo sustentable y conservación del jaguar (Panthera onca) en tres comunidades de la Huasteca Potosina, S. L. P., México. MSc. dissertation, Colegio de Postgraduados, Texcoco, México.

Granados-Herrera J (2008) Percepción geoecológica sobre la fauna silvestre: hacia una mejor estrategia de manejo local. MSc. dissertation, Universidad Nacional Autónoma de México, D.F., México.

Guerra-Pérez A (2011) Recursos naturales etnobiológicos de la Sierra de Tamaulipas (Estado de Tamaulipas, México). MSc. dissertation, Universidad Internacional de Andalucía, Sevilla, España.

Guerra-Roa MM, Naranjo-Piñera EJ, Limón-Aguirre F, Mariaca-Méndez R (2010) Factores que intervienen en la regulación local de la cacería de subsistencia en dos comunidades de la Selva Lacandona, Chiapas. MEMORIAS: Manejo de Fauna Silvestre en Amazonía y Latinoamérica 4: 1-18.

Guerrero-Martínez F (2010) El jaguar (Panthera onca Linnaeus, 1758) y la fertilidad en la pintura mural prehispánica de Cacaxtla, Tlaxcala, México. In: Moreno-Fuentes A, Pulido-Silva MT, Mariaca-Méndez R, Valadez-Azúa R, Mejía-Correa P, Gutiérrez-Santillán TV (eds) Sistemas biocognitivos tradicionales, paradigmas en la conservación biológica y el fortalecimiento cultural. Asociación Etnobiológica Mexicana A.C. - Global Diversity Foundation - El Colegio de la Frontera Sur - Universidad Autónoma del Estado de Hidalgo - Sociedad Latinoamericana de Etnobiología, D.F., pp. 73-80.

Guerrero-Martínez F, Serrano-González R, Serrano-Velázquez R (2010) Aves con atributos pronosticadores, medicinales y mágico-religiosos entre los tojolabales (tojo winik'otik) del ejido Saltillo, Las Margaritas, Chiapas. El Canto del Cenzontle 1(2): 190-203.

Guerrero-Martínez F (2013) Chante'wa xjul b'esniye'. Los animales y sus señales entre los tojolabales de Saltillo, Las Margaritas, Chiapas. MSc. dissertation, Universidad Nacional Autónoma de México, D.F., México.

Guerrero-Ortiz S, Retana-Guiascón OG (2012) Nota científica: uso medicinal de la fauna silvestre por indígenas tlahuicas en Ocuilan, México. Etnobiología 10(2): 28-33.

Guerrero-Ortiz S (2013) Uso medicinal de la fauna silvestre por indígenas tlahuicas en Ocuilan, México. Undergraduate thesis, Universidad Nacional Autónoma de México, D.F., México. 
Guerrero-Sánchez S, Cano-Contreras EJ, Mariaca-Méndez R, Guerrero-Martínez F (2014) Conocimiento local sobre el manejo sanitario de aves de traspatio en dos grupos mayenses del sureste de México. In: Vásquez-Dávila MA (ed) Aves, personas y culturas Estudios de etno-ornitología 1. CONACYT - ITVO - Carteles Editores - UTCH, Oaxaca, pp. 71-81.

Guirao-Cruz R, Gama L, Arriaga-Weiss SL (2014) Aproximación a la cosmovisión y al conocimiento zoque sobre el quetzal (Pharomachrus mocinno) en Tapalapa, Chiapas, México. In: Vásquez-Dávila MA (ed) Aves, personas y culturas Estudios de etno-ornitología 1. CONACYT - ITVO - Carteles Editores - UTCH, Oaxaca, pp. 107-117.

Gutiérrez-del-Ángel A (2010) Amasar, hervir, hornear y comer: el tamal-venado de los wixaritari. Nuevo Mundo Mundos Nuevos doi:10.4000/nuevomundo.66694.

Gutiérrez-Santillán TV (2010) El "camaleón": estudio etnoherpetológico comparativo entre dos comunidades (náhuatl y otomí) en el estado de Hidalgo. Undergraduate thesis, Universidad Autónoma del Estado de Hidalgo, Pachuca, México.

Gutiérrez-Santillán TV, Moreno-Fuentes A, Goyenechea-Mayer I (2010) Cosmos, corpus y praxis: estudio comparativo entre nahuas y otomíes del estado de Hidalgo, México, el caso del "camaléon". In: Moreno-Fuentes A, Pulido-Silva MT, MariacaMéndez R, Valadez-Azúa R, Mejía-Correa P, Gutiérrez-Santillán TV (eds) Sistemas biocognitivos tradicionales, paradigmas en la conservación biológica y el fortalecimiento cultural Asociación Etnobiológica Mexicana A.C. - Global Diversity Foundation - EI Colegio de la Frontera Sur - Universidad Autónoma del Estado de Hidalgo - Sociedad Latinoamericana de Etnobiología, D.F., pp. 81-95

Gutiérrez-Santillán TV (2013) Diversidad biocultural y especies bioculturales clave: Un estudio etnobiológico en dos comunidades nahuas en la Huasteca Hidalguense. MSc. dissertation, Universidad Autónoma del Estado de Hidalgo, Pachuca, México.

Gutiérrez-Santillán TV, Sherbrooke W (2014) Visiting the mexican plateau horned lizard (Phrynosoma orbiculare) at El Parque Ecoturistico "El Camaleón", Hidalgo, México: with historical and ethnobiological commentary. Phrynosomatics the Newletter of the Horned Lizard Conservation Society 19(1): 4-9.

Haemig PD (2010) Ecology and ethnobiology of the slender-billed grackle Quiscalus palustris. Journal of Ornithology 151(2): 391-399 doi:10.1007/s10336-009-0467-2.

Haemig PD (2012) Introduction of the great-tailed grackle (Quiscalus mexicanus) by Aztec emperor Ahuitzotl: provenance of the historical account. The Auk 135(4): 70-75 doi:10.1525/auk.2011.11058.

Haenn N, Schmook B, Reyes Y, Calmé S (2014) Improving conservation outcomes with insights from local experts and bureaucracies. Conservation Biology 28(4): 951-958 doi:10.1111/cobi.12265.

Haenn N, Schmook B, Reyes YM, Calmé S (2014b) A cultural consensus regarding the king vulture?: preliminary findings and their application to Mexican conservation. Ethnobiology and Conservation 3(1): 1-15 doi:10.15451/ec2014-1-3.1-1-15.

Harte-Balzo MA (2007) Estudio de la relación entre los animales y los mexicas, según el relato de fray Bernardino de Sahagún: "Historia de las cosas de Nueva España". Undergraduate thesis, Universidad Nacional Autónoma de México, D.F., México.

Hermann-Lejarazu MA (2009) La serpiente de fuego o yahui en la Mixteca prehispánica: iconografía y significado. Anales del Museo de América 17: 64-77.

Hernández-Aguilar KG, Jamar-de-Bolsée O, Landa-Romo C, Marek O, Smith S, Yeh D (2014) Manejo comunitario de fauna silvestre como una estrategia para el desarrollo de medios de vida sostenible: un caso de estudio en el Ejido Nuevo Becal, Campeche, México. Proyecto Terminal Sinérgico. El Colegio de la Frontera Sur - Colorado State University, San Cristóbal de Las Casas, México.

Hernández-Arciga R (2012) Etnoherpetología en la Sierra Gorda de Guanajuato. In: La biodiversidad en Guanajuato: Estudio de Estado, Vol. II. Comisión Nacional para el Conocimiento y Uso de la Biodiversidad, México, pp. 227-231.

Hernández-Betancourt SF, Segovia-Castillo AH (2010) La cacería de subsistencia en el sur de Yucatán. In: Guerra-Roa M, Calmé S, Gallina-Tessaro S, Naranjo-Piñera EJ (eds) Uso y manejo de fauna silvestre en el norte de Mesoamérica. Gobierno del Estado de Veracruz - Instituto de Ecología - Colegio de la Frontera Sur, México, pp. 32-59.

Hernández-Escampa MA (2010). La construcción social del xoloitzcuintle moderno. In: Moreno-Fuentes A, Pulido-Silva MT, Mariaca-Méndez R, Valadez-Azúa R, Mejía-Correa P, Gutiérrez-Santillán TV (eds) Sistemas biocognitivos tradicionales, paradigmas en la conservación biológica y el fortalecimiento cultural. Asociación Etnobiológica Mexicana A.C. - Global Diversity Foundation - El Colegio de la Frontera Sur - Universidad Autónoma del Estado de Hidalgo - Sociedad Latinoamericana de Etnobiología, D.F., pp. 56-63. 
Hernández-Guzmán J, Morales-García S, Hernández-Cardona A (2009) Biología, importancia y controversias del sapo común Chaunus marinus (Amphibia: Anura: Bufonidae) en Tabasco, México. Kuxulkab' 15(28): 59-64.

Hernández-López A, López-Alamilla E, Rodríguez-Ramírez A, Aquino-Bravata V (2013) Diagnóstico del uso de la fauna silvestre, en el área de protección de flora y fauna "Cañón del Usumacinta" Tenosique, Tabasco. Ra Ximhai 9(1): 1-13.

Hernández-Sánchez I, Bautista-Martínez B (2011) Diccionario de nombres científicos, náhuatl, comunes en español y comunes en inglés de cinco grupos de vertebrados de la Huasteca Hidalguense. Undergraduate thesis, Instituto Tecnológico de Huejutla, Huejutla, México.

Herrera-Pavón RL (2011) La tortuga marina omnipresente en la cultura maya. In: Pozo C, Armijo-Canto N, Calmé S (eds) Riqueza biológica de Quintana Roo. Un análisis para su conservación. El Colegio de la Frontera Sur - Comisión Nacional para el Conocimiento y Uso de la Biodiversidad - Gobierno del Estado de Quintana Roo - Programa de Pequeñas Donaciones, México, pp. 241-247.

Huerta-López A (2012) Etnozoología mazateca como acercamiento a la conservación de fauna silvestre y su hábitat en San José Tenango Oaxaca. Undergraduate thesis, Universidad Autónoma Metropolitana, D.F, México.

Hull K, Fergus R (2011) Ethno-ornithological perspectives on the Ch'ol Maya. Reitaku Reviwe 17: 42-92.

Hunn E (2008) A zapotec natural history; trees, herbs and flowers, birds, beasts, and bugs in the life of San Juan Gbëë. University of Arizona, Arizona, USA.

Ibarra JT (2010) The transition from local hunting to external meat dependency: ethnoecological and socio-cultural effects of a hunting prohibition in the Chinantla Alta Community-based Conservation Area, Oaxaca, Mexico. MSc. dissertation, University of Kent, Canterbury, United Kingdom.

Ibarra JT, Barreau A, Campo C, Camacho Cl, Martin GJ, McCandless SR (2011) When formal and market-based conservation mechanisms disrupt food sovereignty: impacts of community conservation and payments for environmental services on an indigenous community of Oaxaca, Mexico. The Iternational Forestry Review 13(3): 318-337 doi:10.1505/ifor.11.2.155.

Ibarra JT, Campo C, Barreau A, Medinaceli A, Camacho Cl, Puri R, Martin GJ (2011) Etnoecología chinanteca: conocimiento, práctica y creencias sobre fauna y cacería en un área de conservación comunitaria de La Chinantla, Oaxaca, México. Etnobiología 9: 37-59.

Inda-Díaz E, Rodiles-Hernández R, Naranjo EJ, Mendoza-Carranza M (2009) Subsistence fishing in two communities of the Lacandon Forest, Mexico. Fisheries Management and Ecology 16(3): 225-234 doi:10.1111/j.1365-2400.2009.00668.x.

Jacobo-Salcedo MR, Alonso-Castro AJ, Zarate-Martínez A (2011) Folk medicinal use of fauna in Mapimi, Durango, Mexico. Journal of Ethnopharmacology 133(2): 902-906 doi:10.1016/j.jep.2010.10.005.

Jacobo-Salcedo MR, Juárez-Vázquez MC, González-Espíndola LA, Maciel-Torres SP, García-Carrancá A, Alonso-Castro AJ (2013) Biological effects of aqueous extract from turkey vulture Cathartes aura (Cathartidae) meat. Journal of Ethnopharmacology 145(2): 663-666 doi:10.1016/j.jep.2012.11.014.

Jaimes-Yescas MI, Gómez-Álvarez G, Pacheco-Coronel N, Reyes-Gómez SR (2014) Uso y manejo de la avifauna en San Miguel Tzinacapan, municipio de Cuetzalan del Progreso, Puebla, México. In: Vásquez-Dávila MA (ed) Aves, personas y culturas Estudios de etno-ornitología 1. CONACYT - ITVO - Carteles Editores - UTCH, Oaxaca, pp. 243-259.

Jiménez-Díaz JE, Vásquez-Dávila MA, Naranjo-Piñera EJ, Jerez-Salas MP (2014) Las relaciones humano-aves en LacajáChansayab, Selva Lacandona, Chiapas, México. In: Vásquez-Dávila MA (ed) Aves, personas y culturas Estudios de etnoornitología 1. CONACYT - ITVO - Carteles Editores - UTCH, Oaxaca, pp. 83-106.

Kampichler C, Calmé S, Weissenberger H, Arriaga-Weiss SL (2010) Indication of a species in an extinction vortex: the ocellated turkey on the Yucatan Peninsula, Mexico. Acta Oecologica 36(6): 561-568 doi: 10.1016/j.actao.2010.08.004.

Köhler U (2007) Los dioses de los cerros entre los tzotziles en su contexto interétnico. Estudios de Cultura Maya 30: 139-152.

León-Martínez PN (2006) Aprovechamiento de fauna silvestre en una comunidad aledaña a la Reserva de la Biosfera Los Petenes, Campeche. MSc. dissertation, Centro de Investigación y de Estudios Avanzados del Instituto Politécnico Nacional, Mérida, México.

León P, Montiel S (2008) Wild meat use and traditional hunting practices in a rural mayan community of the Yucatan Peninsula, Mexico. Human Ecology 36(2): 249-257 doi:10.1007/s10745-007-9139-0. 
León-Pérez J, Gómez-Álvarez G, Pérez-Peralta O (2009) Etnoanatonomía de los vertebrados en dos comunidades nahuas del volcán Malinche. In: Castro-Pérez F, Tucker TM (eds) Matlalcuéyetl: visiones plurales sobre cultura, ambiente y desarrollo. EI Colegio de Tlaxcala A.C. - CONACYT - Mesoamerican Research Foundation, México, pp. 191-212.

Linares-Aguirre VA (2007) La serpiente de lo cultural a lo biológico. Un estudio lingüístico y etnozoológico del libro XI del Códice Florentino de fray Bernardino de Sahagún. MSc. dissertation, Universidad Nacional Autónoma de México, D.F., México.

Lira-Torres I, Naranjo-Piñera EJ, Reyes-Cahrgoy MA (2005) Ampliación del área de distribución de Tapirus bairdii, Gill 1865 (Perissodactyla: Tapiridae) en Oaxaca, México. Acta Zoológica Mexicana 21(1): 107-110.

Lira-Torres I (2006) Abundancia, densidad, preferencia de hábitat y uso local de los vertebrados en La Tuza de Monroy, Santiago Jamiltepec, Oaxaca. Revista Mexicana de Mastozoología 10: 41-66.

Lira-Torres I, Galindo-Leal C, Briones-Salas M (2012) Mamíferos de la Selva Zoque, México: riqueza, uso y conservación. Revista de Biología Tropical 60(2): 781-797.

Lira-Torres I, Briones-Salas M, Gómez-de-Anda FR, Ojeda-Ramírez D, Peláez-Acero A (2014) Uso y aprovechamiento de la fauna silvestre en la selva Zoque, México. Acta Zoológica Mexicana 30(1): 74-90.

López-Carrera C, Zazueta-Angulo X, Porras-Andujo CR (2005) Notas sobre aprovechamiento del medio ambiente norestense: reconocimiento del terreno, inicio de la cacería. Ra Ximhai 1(1): 177-200.

López-del-Toro P, Andresen E, Estrada A (2009) Attitudes and knowledge of shade-coffee farmers towards vertebrates and their ecological functions. Tropical Conservation Science 2(3): 299-318.

López-Domínguez D (2014) Cwii ts'iaa cantyja 'naa' na nion ndei'nanque' na quitquii nn'ancue ñomndaa suljaa', Ts'ondaa Guerrero. Estudio etnozoológico de los vertebrados utilizados en la alimentación de los amuzgos del municipio de Xochistlahuaca, Guerrero. Undergraduate thesis, Universidad Nacional Autónoma de México, D.F., México.

López-Medellín X, Iñigo-Elías E (2009) La captura de aves silvestres en México: Una tradición milenaria y las estrategias para regularla. Biodiversitas 83: 11-5.

Lorenzo-Monterrubio C, Cruz-Lara LE, Naranjo-Piñera EJ, Barragán-Torres F (2007) Uso y conservación de mamíferos silvestres en una comunidad de las cañadas de la Selva, Lacandona, Chiapas, México. Etnobiología 5: 99-107.

Lujano-Marín B (2013) Etnozoología de los amuzgos de Xochistlahuaca, Guerrero: La danza del jaguar. Undergraduate thesis, Universidad Nacional Autónoma de México, D.F., México.

Mancini A, Senko J, Borquez-Reyes R, Guzmán-Póo J, Seminoff JA, Koch V (2011) To poach or not to poach an endangered species: elucidating the economic and social drivers behind illegal sea turtle hunting in Baja California Sur, Mexico. Human Ecology 39(6): 743-756 doi:10.1007/s10745-011-9425-8.

Martínez-Márquez CA (2011) Etnozoología de ejido Sinaloa 1ra. Sección Cárdenas, Tabasco, México. MSc. dissertation, Colegio de Posgraduados, Cárdenas, Tabasco, México.

Martínez-Pech LG (2011) Valor de uso de la fauna silvestre en la comunidad maya San Antonio Sahcabchén, Campeche, México. Undergraduate thesis, Universidad Autónoma de Campeche, Campeche, México.

Martínez-Torres LM, Vega-Hernández F (2009) Etnomastofauna de la comunidad de Talol, Orizatán, Hidalgo. Undergraduate thesis, Instituto Tecnológico de Huejutla, Huejutla, México.

Martín-Regalado CN, Lavariega MC, Gómez-Ugalde RM (2013) Registro histórico del tapir centroamericano Tapirus bairdii en el Istmo de Tehuantepec, Oaxaca, México. Acta Zoológica Mexicana 29(2): 454-457.

May-Salazar R (2009) Uso de las aves en la comunidad de Dzitbalché, Campeche. Undergraduate thesis, Universidad Autónoma de Campeche, Campeche, México.

Medina-Quej A, Arce-Ibarra AM, Herrera-Pavón R, Caballero-Pinzón P, Ortiz-León H, Rosas-Correa C (2009) Pesquerías: sector social, recurso base y manejo. In: Espinosa-Ávalos J, Hernández-Arana IHA (eds) El sistema ecológico de La Bahía de Chetumal/Corozal: costa occidental del Mar Caribe. El Colegio de la Frontera Sur, México, pp. 184-195.

Méndez-Cabrera F (2005) Estudio preliminar del aprovechamiento de la flora y fauna silvestres en dos comunidades del norte de Campeche. Undergraduate thesis, Universidad Veracruzana, Xalapa, México.

Méndez-Cabrera F, Montiel S (2007) Diagnóstico preliminar de la fauna y flora silvestre utilizada por la población maya de dos comunidades costeras de Campeche, México. Universidad y Ciencia 23(2): 127-139. 
Monroy R, García-Flores A, Monroy-Ortiz R (2011) Importancia de la fauna silvestre en regiones bajo presión inmobiliaria en la Cuenca del Río Grande Amacuzac, Morelos, México. In: Monroy-Martínez R, García-Flores A, Pino-Moreno JM, Monroy-Ortiz R (eds) Etnozoología: Un enfoque binacional México-Colombia. Universidad Autónoma del Estado de México, México, pp. 1940.

Monroy R, Flores G (2013) La fauna silvestre con valor de uso en los huertos frutícolas tradicionales de la comunidad indígena de Xoxocotla, Morelos, México. Etnobiología 11(1): 44-52.

Monroy-Martínez R, Pino-Moreno JM, Lozano-García MA, García-Flores A (2011) Estudio etnomastozoológico en el Corredor Biológico Chichinautzin (COBIO), Morelos, México. Sitientibus Série Ciências Biológicas 11(1): 16-23.

Monroy-Vilchis O, Cabrera L, Suárez P, Zarco-González MM, Rodríguez-Soto C, Urios V (2008) Uso tradicional de vertebrados silvestres en la sierra Nanchititla, México. Interciencia 33(4): 308-313.

Monroy-Vilchis O, Zarco-González M, Rodríguez-Soto C, Suárez P, Urios V (2008) Uso tradicional de reptiles, aves y mamíferos silvestres en la Sierra Nanchititla, México. Universidad Nacional Autónoma de México, Estación Biológica Sierra Nanchichitla, México.

Montaño-Campos S (2008) Conocimiento tradicional de los peces aprovechados en dos comunidades ribereñas del municipio de Calnali, Hidalgo. Undergraduate thesis, Universidad Autónoma del Estado de Hidalgo, Pachuca, México.

Montaño-Campos S, Moreno-Fuentes A, González-Rodríguez KA (2010) Revalorando la pesca náhuatl como ejemplo de una práctica sustentable: estudio de caso en la región hidalguense, México Central. In: Moreno-Fuentes A, Pulido-Silva MT, Mariaca-Méndez R, Valadez-Azúa R, Mejía-Correa P, Gutiérrez-Santillán TV (eds) Sistemas biocognitivos tradicionales, paradigmas en la conservación biológica y el fortalecimiento cultural. Asociación Etnobiológica Mexicana A.C. - Global Diversity Foundation - El Colegio de la Frontera Sur - Universidad Autónoma del Estado de Hidalgo - Sociedad Latinoamericana de Etnobiología, D.F., pp. 317-321.

Montes R (2005) El tepezcuintle, un recurso biológico importante. Biodiversitas 6-11.

Montes-Pérez R, Mukul-Yerves JM (2010) Fauna silvestre como alternativa ganadera. In: Durán R, Méndez M (eds) Biodiversidad y desarrollo humano en Yucatán. CICY - PPD-FMAM - CONABIO - SEDUMA, México, pp. 465-466.

Montiel-Ortega S, Arias-Reyes LM (2008) La cacería tradicional en el mayab contemporáneo: una mirada desde la ecología humana. Avance y Perspectiva 1: 21-27.

Montiel-Ortega S (2010) Diagnóstico en la región de los Petenes. Aprovechamiento de fauna silvestre en la Península de Yucatán: usos y costumbres. Revista Fomix Campeche 29-32.

Morales-Garzón C, Bello-Baltazar E, Estrada-Lugo EIJ, González MJ (2011) Cacería de subsistencia en tres comunidades de la zona maya de México. In: Bello-Baltazar E, Estrada-Lugo EIJ (eds) Cultivar el territorio maya: conocimiento y organización social en el uso de la selva. Universidad Iberoamericana - El Colegio de la Frontera Sur, pp. 133-159.

Morales-Mávil JE, Suárez-Castillo SJ (2010) Conocimiento y uso de tortugas de agua dulce por pescadores y lancheros de Sontecomapan, Veracruz, México. In: Guerra-Roa M, Calmé S, Gallina-Tessaro S, Naranjo-Piñera EJ (eds) Uso y manejo de fauna silvestre en el norte de Mesoamérica. Gobierno del Estado de Veracruz - Instituto de Ecología - Colegio de la Frontera Sur, México, pp. 194-220.

Morales-Vela B, Padilla-Saldívar JA (2011). El manatí. La sirena del Caribe. In: Pozo C, Armijo-Canto N, Calmé S (eds) Riqueza biológica de Quintana Roo: un análisis para su conservación. El Colegio de la Frontera Sur - Comisión Nacional para el Conocimiento y Uso de la Biodiversidad - Gobierno del Estado de Quintana Roo - Programa de Pequeñas Donaciones, México, pp. 248-255.

Morales-Vera T (2006) Las aves de los comcáac (Sonora, México). Undergraduate thesis, Universidad Veracruzana, Xalapa, México.

Morales-Vera T (2012) Música con alas: aves y cantos tradicionales de los comcáac. Biodiversitas 101: 1-5.

Morales-Vera T, Velarde-González E (2014) Las aves y cantos tradicionales de los comcáac de Sonora, México. In: VásquezDávila MA (ed) Aves, personas y culturas Estudios de etno-ornitología 1. CONACYT - ITVO - Carteles Editores - UTCH, Oaxaca, pp. 285-298.

Moreno-Fuentes A, Pulido-Silva MT, Mariaca-Méndez R, Valadez-Azúa R, Mejía-Correa P, Gutiérrez-Santillán TV (2010) Sistemas biocognitivos tradicionales, paradigmas en la conservación biológica y el fortalecimiento cultural. Asociación Etnobiológica Mexicana A.C. - Global Diversity Foundation - El Colegio de la Frontera Sur - Universidad Autónoma del Estado de Hidalgo - Sociedad Latinoamericana de Etnobiología, D.F., México. 
Nabhan GP (2013) The wild, the domesticated, and the coyote-tainted: The trickster and the tricked in hunter-gatherer versus farmer folklore. In: Quinland M, Lepofsky D (eds) Explorations in ethnobiology the legacy of Amadeo Rea. Society of Ethnobiology, Denton, T.X., pp. 162-177.

Naranjo EJ, Bodmer RE (2007) Source-sink systems and conservation of hunted ungulates in the Lacandon Forest, Mexico. Biological Conservation 138(3): 412-420 doi:10.1016/j.biocon.2007.05.010.

Naranjo-Piñera EJ (2008) Uso y conservación de mamíferos en la Selva Lacandona, Chiapas, México. In: Lorenzo C, Espinosa E, Ortega J (eds) Avances en el estudio de los mamíferos de México Il. Asociación Mexicana de Mastozoología, México, pp. 107-123.

Naranjo EJ, López-Acosta JC, Dirzo R (2010) La cacería en México. Biodiversitas 91: 6-10.

Naranjo-Piñera EJ, Guerra-Roa M, Gallina-Tessaro S, Calmé S (2010) Introducción. Uso de fauna silvestre en el norte de Mesoamérica: aspectos generales. In: Guerra-Roa M, Calmé S, Gallina-Tessaro S, Naranjo-Piñera EJ (eds) Uso y manejo de fauna silvestre en el norte de Mesoamérica. Gobierno del Estado de Veracruz - Instituto de Ecología - Colegio de la Frontera Sur, México, pp. 19-24.

Naranjo-Piñera EJ, Tejeda C, Santos-Fita D (2012) El manejo de fauna silvestre en la frontera sur: una perspectiva comunitaria. In: Bello-Baltazar E, Naranjo-Piñera EJ, Vandame R (eds) La otra innovación para el ambiente y la sociedad en la frontera sur de México. El Colegio de la Frontera Sur - Red de Espacios de Innovación Socioambiental - Comisión Nacional de Ciencia y Tecnología, México, pp. 59-69.

Naranjo-Piñera EJ (2013) Uso de la fauna silvestre. In: La biodiversidad en Chiapas. Estudio de Estado Vol. 1. Comisión Nacional para el Conocimiento y Uso de la Biodiversidad, Gobierno del Estado de Chiapas, México, pp. 271-280.

Naranjo-Piñera EJ, Rangel-Salazar JL, Tejeda-Cruz C (2014) El manejo comunitario de fauna silvestre como instrumento para la conservación en Marqués de Comillas, Selva Lacandona, Chiapas. In: Medina-Sansón L, Tejeda-Cruz C, Carrillo-Reyes A, Rioja-Paradela TM (eds) Gestión territorial y manejo de recursos naturales: Fauna silvestre y sistemas agropecuarios. Universidad Nacional Autónoma de Chiapas, México, pp. 149-173.

Navarijo-Ornelas ML (2011) Guacamaya: Símbolo de temporalidad y fertilidad en dos ejemplos de pintura mural. Estudios de Cultura Maya 173-194.

Navarro-Smith A, Tapia-Landeros A, Garduño E (2010) Navegando a contracorriente. Los cucupá y la legislación ambiental. Culturales VI: 43-74.

Neurath J (2008) Cacería ritual y sacrificios huicholes: entre depredación y alianza, intercambio e identificación. Journal de la Société des Américanistes 94(1) 251-283.

Niño-Gómez G (2009) Uso de la fauna silvestre en la comunidad maya de Pich, Campeche, México. Undergraduate thesis, Universidad Autónoma de Campeche, Campeche, México.

Núñez-Durán E, Aguilar-Cordero W, Hernández-Betancourt SF (2010) Conocimiento tradicional sobre el uso y aprovechamiento de la fauna silvestre en la Reserva Municipal de Cuxtal, Yucatán, México. In: Moreno-Fuentes A, Pulido-Silva MT, Mariaca-Méndez R, Valadez-Azúa R, Mejía-Correa P, Gutiérrez-Santillán TV (eds) Sistemas biocognitivos tradicionales, paradigmas en la conservación biológica y el fortalecimiento cultural. Asociación Etnobiológica Mexicana A.C. - Global Diversity Foundation - El Colegio de la Frontera Sur - Universidad Autónoma del Estado de Hidalgo - Sociedad Latinoamericana de Etnobiología, D.F., pp. 457-464.

Núñez-García RM, Fuente-Castro ME, Venegas-Barrera CS (2012) La avifauna en la memoria biocultural de la juventud indígena en la Sierra Juárez de Oaxaca, México. Universidad y Ciencia 28(3): 201-216.

Oliva M (2013) La gestión ambiental y el aprovechamiento local contemporáneo de fauna silvestre: el caso de la reserva de la biósfera Los Petenes, Campeche. MSc. dissertation, Centro de Estudios Avanzados del Instituto Politécnico Nacional, Mérida, México.

Oliva M, Montiel S, García A, Vidal L (2014) Local perceptions of wildlife use in Los Petenes Biosphere Reserve, Mexico: maya subsistence hunting in a conservation conflict context. Tropical Conservation Science 7(4): 781-795.

Pablo-Rodríguez N, Olivera-Gómez LD (2012) Situación de una población aislada de manatíes Trichechus manatus (Mammalia: Sirenia: Trichechidae) y conocimiento de la gente, en una laguna urbana, en Tabasco, México. Universidad y Ciencia 28(1): 15-26. 
Padilla SE, Perera-Trejo E (2010) Anotaciones sobre la percepción del cocodrilo de pantano por las comunidades mayas aledañas a la Reserva de la Biosfera Los Petenes. Revista Latinoamericana de Conservación 1(2): 83-90.

Parcero-Vázquez WA, Trejo-Pérez JL (2014) Aprovechamiento de psitácidos en cautiverio en la Villa Luis Gil Pérez, Centro, Tabasco, México. In: Vásquez-Dávila MA (ed) Aves, personas y culturas Estudios de etno-ornitología 1. CONACYT - ITVO Carteles Editores - UTCH, Oaxaca, pp. 47-52.

Parroquín-Pérez J, Gallina-Tessaro S, Aguirre-León G, Pérez-Torres J (2010) El tepezcuintle: estrategias para su aprovechamiento con base en la evaluación de su población y hábitat en el ejido Loma de Oro, Uxpanapa, Veracruz, México. In: Guerra-Roa M, Calmé S, Gallina-Tessaro S, Naranjo-Piñera EJ (eds) Uso y manejo de fauna silvestre en el norte de Mesoamérica. Gobierno del Estado de Veracruz - Instituto de Ecología - Colegio de la Frontera Sur, México, pp. 137-160.

Pascual-Ramos E, Medina-Torres SM, Sandoval-Forero A, Lara-Ponce E, Piña-Ruíz HH, Martínez-Ruíz R, Rojo-Martínez GE (2014) Uso de reptiles entre yoremes y yoris en el municipio de El Fuerte, Sinaloa. Ra Ximhai 10(3): 195-208.

Penguilly-Macias A, Moreno-Fuentes A, Goyenechea-Mayer I, Espinosa-Pineda G (2010) Percepción acerca de las lagartijas consideradas nocivas por algunos otomíes, nahuas, tepehuas y mestizos en el estado de Hidalgo, México. In: Moreno-Fuentes A, Pulido-Silva MT, Mariaca-Méndez R, Valadez-Azúa R, Mejía-Correa P, Gutiérrez-Santillán TV (eds) Sistemas biocognitivos tradicionales, paradigmas en la conservación biológica y el fortalecimiento cultural. Asociación Etnobiológica Mexicana A.C. Global Diversity Foundation - El Colegio de la Frontera Sur - Universidad Autónoma del Estado de Hidalgo - Sociedad Latinoamericana de Etnobiología, D.F., pp. 99-104.

Peña-Mondragón JL, García A, Vega-Rivera JH, Castillo A (2013) Interacciones y percepciones sociales con cocodrilo de río (Crocodylus acutus) en la costa sur de Jalisco, México. Revista de Biodiversidad Tropical 3(1): 37-41.

Peres TM, VanDerwarker AM, Pool A (2010) The farmed and the hunted: integrating floral and faunal data from Tres Zapotes, Veracruz. In: VanDerwarker AM, Peres TM (eds) Integrating zooarchaeology and paleoethnobotany: A consideration of issues, methods and cases. Springer, USA, pp. 287-308

Pérez-González LS, González-Rodríguez KA, Moreno-Fuentes A (2012) Aprovechamiento y conocimiento tradicional ictiológico; documentación sobre la pesca en el municipio de Jacala de Ledesma, Hidalgo, México. XXIX Mesa Redonda, Sociedad Mexicana de Antropología, México.

Pérez-Hernández Y, López-Téllez MC. Evaluación de los usos de los mamíferos silvestres en el ejido Rancho El Salado, Jolalpan, Puebla, México. In: Moreno-Fuentes A, Pulido-Silva MT, Mariaca-Méndez R, Valadez-Azúa R, Mejía-Correa P, Gutiérrez-Santillán TV (eds) Sistemas biocognitivos tradicionales, paradigmas en la conservación biológica y el fortalecimiento cultural. Asociación Etnobiológica Mexicana A.C. - Global Diversity Foundation - El Colegio de la Frontera Sur - Universidad Autónoma del Estado de Hidalgo - Sociedad Latinoamericana de Etnobiología, D.F., pp. 465-471.

Pérez-Sánchez E, Rodríguez-Quevedo F, Zequeira-Larios C, Cruz-Vera J, Ovando-Hidalgo N (2006) Las comunidades rurales del cocodrilo de pantano (Crocodylus moreletii) en la reserva de la biosfera Pantanos de Centla. Kuxulkab' XI(22): 29-34.

Pires S, Clarke RV (2012) Are parrots CRAVED? An analysis of parrot poaching in Mexico. Journal of Research in Crime and Delinquency 49(1): 122-146 doi:10.1177/0022427810397950.

Puc-Gil RA (2009) Valor de uso de la fauna silvestre en la comunidad maya Villa de Guadalupe, Campeche, México. Undergraduate thesis, Universidad Autónoma de Campeche, Campeche, México.

Puc-Gil RA, Retana-Guiascón OG (2012) Uso de la fauna silvestre en la comunidad maya Villa de Guadalupe, Campeche, México. Etnobiología 10(2): 1-11.

Ramírez-Barajas PB, Naranjo-Piñera EJ (2007) La cacería de subsistencia en una comunidad de la zona maya, Quintana Roo, México. Etnobiología 5: 65-85.

Ramírez-Barajas PJ, Calmé S (2015) Biodiversity and conservation of the Yucatán Peninsula. In: Islebe GA, Calmé S, LeónCortés JL, Schmook B (eds) Subsistence hunting and conservation. Springer, Switzerland, doi:10.1007/978-3-319-06529-8.

Ramírez-Vera B, López-Téllez MC, Yanes-Gómez G (2011) Usos tradicionales de la fauna silvestre. In: La biodiversidad de Puebla. Estudio de Estado. Comisión Nacional para el Conocimiento y Uso de la Biodiversidad, México, pp. 267-283.

Retana-Guiascón OG (2010) Los murciélagos, elementos de expresión cultural en Mesoamérica. In: Moreno-Fuentes A, Pulido-Silva MT, Mariaca-Méndez R, Valadez-Azúa R, Mejía-Correa P, Gutiérrez-Santillán TV (eds) Sistemas biocognitivos tradicionales, paradigmas en la conservación biológica y el fortalecimiento cultural. Asociación Etnobiológica Mexicana A.C. Global Diversity Foundation - El Colegio de la Frontera Sur - Universidad Autónoma del Estado de Hidalgo - Sociedad Latinoamericana de Etnobiología, D.F., pp. 472-475. 
Retana-Guiascón OG (2010) Unidades de manejo comunitarias. Revista Fomix Campeche 37-40.

Retana-Guiascón OG (2012) Nota Científica: Una aproximación al proceso de conocimiento del mundo natural por una comunidad chinanteca. Etnobiología 10(1): 60-65.

Retana-Guiascón OG, Navarijo-Ornelas ML (2012) Los valores culturales de los murciélagos. Revista Mexicana de Mastozoología Nueva Época 2(1): 18-26.

Retana-Guiascón OG, Puc-Gil RA, Martínez-Pech LG (2014) Uso artesanal de la vida silvestre por comunidades mayas, Campeche, México: el caso de las aves. In: Vásquez-Dávila MA (ed) Aves, personas y culturas Estudios de etno-ornitología 1. CONACYT - ITVO - Carteles Editores - UTCH, Oaxaca, pp. 35-46.

Retana-Guiascón OG, Martínez-Pech LG, Niño-Gómez G, Victoria-Chan E, Cruz-Mass A, Uc-Piña A (2015) Patrones y tendencias de uso del venado cola blanca (Odocoileus virginianus) en comunidades mayas, Campeche, México. Therya 6(3): 597-608 doi:10.12933/therya-15-313.

Reuter A, Mosig P (2010) Comercio y aprovechamiento de especies silvestres en México: observaciones sobre la gestión, tendencias y retos relacionados. TRAFFIC, USA.

Reyes-Trigos VY (2010) Representaciones culturales (conocimiento, cosmos y aprovechamiento) de los mamíferos silvestres en Cerro Mirador y San Mateo Yetla, Oaxaca. Undergraduate thesis, Universidad Nacional Autónoma de México, D.F., México.

Reyna-Hurtado RA, Tanner GW (2010) Efecto de la perturbación humana en la abundancia relativa de ungulados en tres comunidades de la región de Calakmul, Campeche, México. In: Guerra-Roa M, Calmé S, Gallina-Tessaro S, Naranjo-Piñera EJ (eds) Uso y manejo de fauna silvestre en el norte de Mesoamérica. Gobierno del Estado de Veracruz - Instituto de Ecología Colegio de la Frontera Sur, México, pp. 115-135.

Reyna-Hurtado R, Tanner GW (2005) Habitat preferences of ungulates in hunted and non hunted areas in the Calakmul Forest, Campeche, Mexico. Biotropica 37(4): 676-685 doi:10.1111/j.1744-7429.2005.00086.x.

Reyna-Hurtado R, Tanner GW (2007) Ungulate relative abundance in hunted and non-hunted sites in Calakmul Forest (Southern Mexico). Biodiversity and Conservation 16(3): 743-756 doi:10.1007/s10531-005-6198-7.

Reyna-Hurtado R, Naranjo E, Chapman CA, Tanner GW (2009) Hunting and the conservation of a social ungulate: the whitelipped peccary Tayassu pecari in Calakmul, Mexico. Oryx 44(1): 89-96 doi:10.1017/S0030605309990664.

Reyna-Rojas MA, García-Flores A, Neri-Castro EE, Alagón-Cano A, Monroy-Martínez R (2015) Conocimiento etnoherpetológico de dos comunidades aledañas a la reserva estatal sierra de Montenegro, Morelos, México. Etnobiología 13(2): 37-48.

Rodas-Trejo J, Romero-Berny El, Estrada A (2008) Distribution and conservation of the west indian manatee (Trichechus manatus manatus) in the Catazaja wetlands of northeast Chiapas, Mexico. Tropical Conservation Science 1(4): 321-333.

Rodas-Trejo J, Romero-Berny EI, Moreno-Molina EB (2012) Conocimiento biológico, usos y actitudes hacia el manatí (Trichechus manatus manatus) por los pobladores del sistema de humedales Catazajá-La Libertad, Chiapas, México. Lacandonia 6(2): 91-99.

Rodríguez M, Montiel S, Cervera MD, Castillo MT, Naranjo EJ (2012) The practice and perception of batida (group hunting) in a maya community of Yucatan, Mexico. Journal of Ethnobiology 38(3): 212-227 doi:10.2993/0278-0771-32.2.212.

Rodríguez-Pérez V (2013) Percepciones ambientales de jóvenes mayas de Quintana Roo. MSc. dissertation, El Colegio de la Frontera Sur, San Cristóbal de Las Casas, México.

Rodríguez-Valencia M (2010) Diagnóstico socioambiental de la cacería en grupo o batida en una comunidad maya de Campeche. MSc. dissertation, Centro de Investigación y de Estudios Avanzados del Instituto Politécnico Nacional, Mérida, México.

Roldán-Clarà B, López-Medellín X, Espejel I, Arellano E (2014) Literature review of the use of birds as pets in Latin-America, with a detailed perspective on Mexico. Ethnobiology and Conservation 3:5 doi:10.15451/ec2014-10-3.5-1-18.

Romero-Balderas KG, Naranjo EJ, Morales HH, Nigh RB (2006) Daños ocasionados por vertebrados silvestres al cultivo de maíz en la Selva Lacandona, Chiapas, México. Interciencia 31(4): 276-283.

Romero-González MP (2013) Percepciones de niñas y niños sobre las aves en primarias rurales y urbanas en San Cristóbal de Las Casas, Chiapas. MSc. dissertation, El Colegio de la Frontera Sur, San Cristóbal de Las Casas, México. 
Romero-González P, Enríquez PL, Álvarez-Gordillo G (2014) Conocimientos y percepciones de niñas y niños sobre las aves en San Cristóbal de Las Casas, Chiapas, México. In: Vásquez-Dávila MA (ed) Aves, personas y culturas Estudios de etnoornitología 1. CONACYT - ITVO - Carteles Editores - UTCH, Oaxaca, pp. 133-150.

Ruano-Escalante YR (2011) Viabilidad económica e implicaciones de conservación de las UMA intensivas de venado cola blanca (Odocoileus virginianus) en Yucatán. MSc. dissertation, Centro de Investigación y de Estudios Avanzados del Instituto Politécnico Nacional, Mérida, México.

San Diego Archaeological Center (2015, Aug. 18). Anthropology of Baja California, Databases, Ethnobiology of Baja California. Recovered from: http://www.sandiegoarchaeology.org/Laylander/Baja/bio.htm

Sánchez-Núñez E (2005) Conocimiento tradicional mazahua de la herpetofauna: un estudio etnozoológico en la Reserva de la Biósfera Mariposa Monarca, México. Estudios Sociales 15: 43-66.

Sántiz-Ruiz G, Perezgrovas-Garza R, Rodríguez-Galván G, Zaragoza-Martínez L (2014) Importancia socioeconómica y cultural de las gallinas locales en una comunidad tsotsil de Chiapas, México. In: Vásquez-Dávila MA (ed) Aves, personas y culturas Estudios de etno-ornitología 1. CONACYT - ITVO - Carteles Editores - UTCH, Oaxaca, pp. 119-132.

Santos-Fita D, Sánchez-Salinas S, Fuentes-Jiménez A, Costa-Neto E (2006) Etnoentomología en el municipio de San Antonio Cuaxomulco, Tlaxcala, México: un estudio de caso sobre los diferentes usos que se les da a los "insectos". Sitientibus série Ciências Biológicas 6: 72-79.

Santos-Fita D, Argueta-Villamar A, Astorga-Domínguez M, Quiñones-Martínez M (2012a) La etnozoología en México: La producción bibliográfica del siglo XXI (2000-2011). Etnobiología 10(1): 41-51.

Santos-Fita D, Argueta-Villamar A, Astorga-Domínguez M, Quiñones-Martínez M (2012b) Información complementaria: La etnozoología en México: La producción bibliográfica del siglo XXI (2000-2011). Etnobiología 10(1): 41-51.

Santos-Fita D, Naranjo EJ, Rangel-Salazar JL (2012c) Wildlife uses and hunting patterns in rural communities of the Yucatan Peninsula, Mexico. Journal of Ethnobiology and Ethnomedicine 8:38 doi:10.1186/1746-4269-8-38.

Santos-Fita D (2013) Cacería de subsistencia, manejo y conservación de fauna silvestre en comunidades rurales de la Península de Yucatán, México. PhD Thesis, El Colegio de la Frontera Sur, San Cristóbal de Las Casas, México.

Santos-Fita D, Naranjo-Piñera EJ, Estrada-Lugo E, Mariaca-Méndez R, Macario-Mendoza PA (2013) La milpa comederotrampa como una estrategia de cacería tradicional maya. Estudios de Cultura Maya XLII: 87-118.

Santos-Fita D, Naranjo EJ, Estrada E, Mariaca R, Bello E (2015) Symbolism and ritual practices related to hunting in maya communities from central Quintana Roo, Mexico. Journal of Ethnobiology and Ethnomedicine 11:71 doi:10.1186/s13002-0150055-x.

Saucedo-Sánchez ER (2007) Notas y reflexiones etnográficas en torno a la fauna y su relación con la región celeste del cosmos rarámuri. Cuicuilco 14(39): 79-98.

Saumade F (2013) Toro, venado, maíz peyote: El cuadrante de la cultura wixarika. Revista El Colegio de San Luis Potosí III(5): 16-54.

Secretaría de Educación Pública (2010) Venados: animales de los dioses. Secretaria de Educación de Veracruz - Instituto de Ecología A.C., México.

Segovia-Castillo AH, Chablé-Santos J, Delfín-González H, Sosa-Escalante JE, Hernández-Betancourt SF (2010) Aprovechamiento de la fauna silvestre por comunidades mayas. In: Durán R, Méndez M (eds) Biodiversidad y desarrollo humano en Yucatán. CICY - PPD-FMAM - CONABIO - SEDUMA, México, pp. 385-387.

Segovia-Castillo AH, Sosa-Escalante JE, Alonso-Parra D, Chablé-Santos J (2010) Aprovechamiento cinegético de aves acuáticas migratorias. In: Durán R, Méndez M (eds) Biodiversidad y desarrollo humano en Yucatán. CICY - PPD-FMAM CONABIO - SEDUMA, México, pp. 388-391.

Serrano-González R, Guerrero-Martínez F, Serrano-Velázquez R (2011) Animales medicinales y agoreros entre tzotziles y tojolobales. Estudios Mesoamericanos 11: 29-42.

Serrano-González R (2014) Yolcapahtiliztli ompa tlacotenco, malacachtepec momoxco. Recursos zooterapéuticos en Santa Ana, Milpa Alta. MSc. dissertation, Universidad Nacional Autónoma de México, D.F., México.

Solís-Rojas L (2006) Etnoecología cuicateca en San Lorenzo Pápalo, Oaxaca. MSc. dissertation, Universidad Nacional Autónoma de México, D.F., México. 
Soriano-Arista MCE (2007) Anfibios y reptiles de los municipios de Amatlán y Cervantes, Veracruz y sus aspectos etnoherpetológicos. Undergraduate thesis, Universidad Nacional Autónoma de México, D.F., México.

Sosa-Escalante JE (2011) Aplicación de la ley para el combate del tráfico ilegal de vida silvestre en México: El caso de Charco Cercado. Therya 2(3): 245-262 doi:10.12933/therya-11-53.

Tapia-Landeros A (2006) Un río y sus pescadores nativos en peligro de extinción. Revista UABC 75: 74-80.

Tapia-Landeros A, Grijalva A (2012) El imaginario colectivo kumiai y sus recursos naturales. Estudios Fronterizos 13(25): 131156.

Tapia-Landeros A, Magaña-Mancillas MA (2014) Registros históricos de la cinegética en Baja California: prácticas culturales de cazadores indígenas y deportivos. Letras Históricas 9: 227-250.

Tejeda-Cruz C (2009) Ecología, conservación y manejo de ungulados silvestres en paisajes fragmentados de la Selva Lacandona, Chiapas, México. PhD Thesis, El Colegio de la Frontera Sur, San Cristóbal de Las Casas, México.

Tejeda-Cruz C (2011) Los retos para el manejo comunitario de fauna silvestre en la Selva Lacandona, Chiapas, México. In: Contreras-Hernández A, Kauffer-Michel EF (eds) La encrucijada del México rural contrastes regionales en un mundo desigual. Tomo VI Recursos naturales, instituciones locales y política ambientales: las encrucijadas de la conservación en México. Asociación Mexicana de Estudios Rurales México, México, pp. 115-142.

Tejada-Cruz C, Naranjo-Piñera EJ, López S, Espinosa-Medinilla EE, Rioja T, Medina-Sansón L, Mendoza-Nazar P, RivasPlateros GG (2011) Aprovechamiento de fauna silvestre para autoconsumo en áreas naturales protegidas: Estrategias de uso y conservación de la biodiversidad para comunidades rurales de la Selva Lacandona, Chiapas, México. In: Síntesis para decisores. Solucions for enviroment and developmen, pp. 506-507.

Tejeda-Cruz C, Naranjo-Piñera EJ, Medina-Sansón LM, Guevara-Hernández F (2014) Cacería de subsistencia en comunidades rurales de la Selva Lacandona, Chiapas, México. Quehacer Científico en Chiapas 9(1): 59-73.

Tlapaya L, Gallina S (2010) Cacería de mamíferos medianos en cafetales del centro de Veracruz, México. Acta Zoológica Mexicana 26(2): 259-277.

Toledo VM, Barrera-Bassols N, García-Frapolli E, Alarcón-Cháires P (2007) Manejo y uso de la biodiversidad entre los mayas yucatecos. Biodiversitas 70: 10-15.

Toledo VM, Barrera-Bassols N, García-Frapolli E, Alarcón-Cháires P (2008) Uso múltiple y biodiversidad entre los mayas yucatecos (México). Interciencia 33(5): 345-352.

Torre-Loranca MA, Aguirre-León G, Contreras-Hernández A (2010) El manejo comunitario de las poblaciones de tortugas dulceacuícolas en el ejido La Margarita, Catemaco, Veracruz, México. In: Guerra-Roa M, Calmé S, Gallina-Tessaro S, NaranjoPiñera EJ (eds) Uso y manejo de fauna silvestre en el norte de Mesoamérica. Gobierno del Estado de Veracruz - Instituto de Ecología - Colegio de la Frontera Sur, México, pp. 107-134.

Torres-García IE (2006) Representaciones y usos de los animales silvestres y domésticos entre los teenek de la Huasteca Potosina. Undergraduate thesis, Universidad Autónoma Metropolitana, D.F., México.

Trejo-Pérez JL (2006) Aprovechamiento de las aves silvestres en Boca del Cerro municipio de Tenosique, Tabasco, Mex. Kuxulkab' 59-63.

Tuz-Canché MG (2014) Conocimiento tradicional de plantas medicinales usadas como antídoto ante la fauna venenosa en el Área de Protección de Flora y Fauna Otoch Ma'ax yetel Kooh, Yucatán, México. Undergraduate thesis, Universidad Autónoma de Yucatán, Mérida, México.

Uc-Keb M (2014) Ideas y prácticas sobre las aves entre los niños mayas de Xcunyá, Yucatán. MSc. dissertation, Centro de Investigación y de Estudios Avanzados del Instituto Politécnico Nacional, Mérida, México.

Uc-Keb M, Cervera-Montejano MD (2014) ¡Vamos a Pescar!: Los niños mayas y las aves de Yucatán, México. In: VásquezDávila MA (ed) Aves, personas y culturas Estudios de etno-ornitología 1. CONACYT - ITVO - Carteles Editores - UTCH, Oaxaca, pp. 19-34.

Uc-Piña A (2010) Valoración de uso de la fauna silvestre en la comunidad maya de Nunkiní, Calkiní, Campeche. Undergraduate thesis, Universidad Autónoma del Estado de Campeche, Campeche, México.

Uriarte-Garzón P (2012) El conocimiento etnoherpetológico dentro de las comunidades del área natural protegida Cerro de Arandas, Irapuato. In: La biodiversidad en Guanajuato, Estudio de Estado, Vol. II. Comisión Nacional para el Conocimiento y Uso de la Biodiversidad - Instituto de Ecología de Guanajuato, México, pp. 241-243. 
Valdez R, Guzmán-Aranda JC, Abarca FJ, Tarango-Arámbula LA, Sánchez FC (2006) Wildlife conservation and management in Mexico. Wildlife Society Bulletin 34(2): 270-282.

Vargas-Clavijo M, Cano-Contreras E (2015) Culebra guardacaminos ¿por qué me quieres picar?: representaciones culturales alrededor de la mordedura de serpiente entre colombianos y mexicanos. Ouricuti 5(1): 145-167.

Vásquez-Cruz R, Vásquez-Dávila MA, Montaño-Contreras EA, Jerez-Salas MP (2014) Ornitología zapoteca de San José Quianitas, Sierra Sur de Oaxaca, México. In: Vásquez-Dávila MA (ed) Aves, personas y culturas Estudios de etno-ornitología 1. CONACYT - ITVO - Carteles Editores - UTCH, Oaxaca, pp. 187-205.

Vásquez-Dávila MA, Lope-Alzina D (2012) Aves y huertos de México. Consejo Nacional de Ciencia y Tecnología, México.

Vásquez-Dávila MA (2014) Aves, personas y culturas: Estudios de etno-ornitología 1. CONACYT - ITVO - Carteles Editores UTCH, Oaxaca, México.

Vásquez-Dávila MA, Camacho-Escobar MA, Jerez-Salas MP, Villegas-Aparicio Y (2014) Los patos (Anatidae): Recurso zoogenético de los grupos étnicos del Sureste de México. Actas Iberoamericanas de Conservación Animal 4, 313-315.

Vásquez-Dávila MA, Camacho-Escobar MA, López-Luis D, Vásquez-Cruz R, Jiménez-Díaz JE (2014) Aprovechamiento tradicional y cría en cautiverio de chachalacas, pava y faisán (Cracidae) en el Sur de México. Actas Iberoamericanas de Conservación Animal 4: 311-312.

Vázquez L-B, Gaston KJ (2006) People and mammals in Mexico: Conservation conflicts at a national scale. Biodiversity and Conservation 15(8): 2397-2414 doi:10.1007/s10531-004-3954-z.

Vázquez-García V, Godínez-Guevara ML (2005) Cambio social y estatus masculino en la cacería indígena. Un estudio de caso del sureste veracruzano. Relaciones 103: 135-167.

Velarde-Ebergenyi S, Cruz-León A (2015) La fauna silvestre y su relación con el bienestar de tres comunidades de la Reserva de la Biosfera Sierra de Huautla, Morelos. Etnobiología 1: 39-52.

Velarde-Mendoza T (2011) Importancia ecológica y cultural de una especie endémica de ajolote (Ambystoma dumerilii) del lagode Pátzcuaro, Michoacán. Undergraduate thesis, Universidad Nacional Autónoma de México, D.F., México.

Victoria-Chan E (2008) Uso de la fauna silvestre en la comunidad maya de Chencoh, municipio de Hopelchen, Campeche, México. Undergraduate thesis, Universidad Autónoma de Campeche, Campeche, México.

Vidaña-Tavera $Y$ (2008) Aprovechamiento comunitario de fauna silvestre bajo el esquema de unidades de producción extensiva. El caso de Carlos Caso Cruz, Campeche, México. Undergraduation thesis, Universidad Autónoma de Campeche, Campeche, México.

Weber M, García-Marmolejo G, Reyna-Hurtado R (2006) The tragedy of the commons: wildlife management units in southeastern Mexico. Wildlife Society Bulletin 34(5): 1480-1488.

Zamora-Suárez VE (2013) Comercio de aves silvestres canoras y de ornato vivas en la ciudad de Xalapa, Ver., implicaciones ecológicas, sanitarias y sociales. Undergraduate thesis, Universidad Veracruzana, Xalapa, México.

Zamudio F, Bello-Baltazar E, Estrada-Lugo E (2013) Learning to hunt crocodiles: social organization in the process of knowledge generation and the emergence of management practices among mayan of Mexico. Journal of Ethnobiology and Ethnomedicine 9:35 doi:10.1186/1746-4269-9-35.

Zamudio F, Bello-Baltazar E, Estrada-Lugo EIJ (2011) Integrando conocimientos mayas y científicos sobre el lagarto (Crocodylus moreletii) en el ejido de Xhazil Sur y Anexos, Quintana Roo, México. In: Bello-Baltazar E, Estrada-Lugo EIJ (eds)Cultivar el territorio maya: conocimiento y organización social en el uso de la selva. Universidad Iberoamericana - EI Colegio de

la Frontera Sur, México, pp. 161-188. 